\title{
Water near its Supercritical Point and at Alkaline pH for the Production of Ferric Oxides and Silicates in Anoxic Conditions. A New Hypothesis for the Synthesis of Minerals Observed in Banded Iron Formations and for the Related Geobiotropic Chemistry inside Fluid Inclusions
}

\author{
Marie-Paule Bassez ${ }^{1}$ (D)
}

Received: 24 January 2018 / Accepted: 24 June 2018 /

Published online: 8 August 2018

(C) The Author(s) 2018

\begin{abstract}
An alternative hypothesis for the origin of the banded iron formations and the synthesis of prebiotic molecules is presented here. I show the importance of considering water near its supercritical point and at alkaline $\mathrm{pH}$. It is based on the chemical equation for the anoxic oxidation of ferrous iron into ferric iron at high-subcritical conditions of water and high $\mathrm{pH}$, that $\mathrm{I}$ extract from E-pH diagrams drawn for corrosion purposes (Geophysical Research Abstracts Vol 15, EGU2013-22 Bassez 2013, Orig Life Evol Biosph 45(1):5-13, Bassez 2015, Procedia Earth Planet Sci 17, 492495, Bassez 2017a, Orig Life Evol Biosph 47:453-480, Bassez 2017b). The sudden change in solubility of silica, $\mathrm{SiO}_{2}$, at the critical point of water is also considered. It is shown that under these temperatures and pressures, ferric oxides and ferric silicates can form in anoxic terrains. No $\mathrm{Fe}^{\mathrm{II}}$ oxidation by UV light, neither by oxygen is needed to explain the minerals of the Banded Iron Formations. The intervention of any kind of microorganisms, either sulfate-reducing, or $\mathrm{Fe}^{\mathrm{II}}$ oxidizing or $\mathrm{O}_{2}$-producing, is not required. The chemical equation for the anoxic oxidation of ferrous iron is applied to the hydrolyses of fayalite, $\mathrm{Fe}_{2} \mathrm{SiO}_{4}$ and ferrosilite, $\mathrm{FeSiO}_{3}$. It is shown that the $\mathrm{BIF}$ minerals of the Hamersley Group, Western Australia, and the Transvaal Supergroup, South Africa, are those of fayalite and ferrosilite hydrolyses and carbonations. The dissolution of crustal fayalite and ferrosilite during water-rock interaction needs to occur at T\&P just below the critical point of water and in a rising water which is undersaturated in $\mathrm{SiO}_{2}$. Minerals of $\mathrm{BIFs}$ which can then be ejected at the surface from venting arcs are ferric oxide hydroxides, hematite, $\mathrm{Fe}^{\mathrm{III}}$-greenalite, siderite. The greenalite dehydrated product minnesotaite forms when rising water becomes supersaturated in $\mathrm{SiO}_{2}$, as also riebeckite and stilpnomelane. Long lengths of siderite without ferric oxides neither ferric silicates can occur since the exothermic siderite formation is not so much dependent in T\&P. It is also shown that the $\mathrm{H}_{2}$ which is released during hydrolysis/oxidation of fayalite/ferrosilite can lead to
\end{abstract}

Marie-Paule Bassez

marie-paule.bassez@unistra.fr; mpbassez@hotmail.com; http://chemphys.u-strasbg.fr/mpb

1 Institut de Technologie, Université de Strasbourg, 67400 Illkirch-Graffenstaden, Strasbourg, France 
components of life, such as macromolecules of amino acids which are synthesized from mixtures of $\left(\mathrm{CO}, \mathrm{N}_{2}, \mathrm{H}_{2} \mathrm{O}\right)$ in Sabatier-Senderens/Fischer-Tropsch \& Haber-Bosch reactions or microwave or gamma-ray excitation reactions. I propose that such geobiotropic synthesis may occur inside fluid inclusions of BIFs, in the silica chert, hematite, $\mathrm{Fe}^{\mathrm{III}}$-greenalite or siderite. Therefore, the combination of high-subcritical conditions of water, high solubility of $\mathrm{SiO}_{2}$ at these $\mathrm{T} \& \mathrm{P}$ values, formation of CO also at these T\&P, high $\mathrm{pH}$ and anoxic water, leads to the formation of ferric minerals and prebiotic molecules in the process of geobiotropy.

Keywords Anoxic iron oxidation - Abiogenic ferric iron · High-subcritical water · High pH Ferrous/ferric iron · Ferric oxide hydroxides $\cdot$ Ferric oxides $\cdot$ Ferric silicates $\cdot$ Amorphous silica · Banded Iron Formations · Hamersley Group · Transvaal Supergroup · Prebiotic matter · Fluid inclusions · Amino-acids · Geobiotropy $\cdot$ Geobiotropic chemistry $\cdot$ Geochemical origin of life Theoretical \& experimental work $\cdot$ Raman analysis

\section{Introduction}

Below I present an alternative to the usually accepted theory that ferric oxides form in the presence of UV light, oxygen, or microorganisms, introducing my 2013 proposition that they form through anoxic oxidation of $\mathrm{Fe}^{\mathrm{II}}$ in high-subcritical water and high $\mathrm{pH}$, and that this process can lead to the formation of prebiotic molecules in the process of geobiotropy. I apply this anoxic oxidation to banded iron formations.

Ferrous and ferric oxides have been extensively studied. Books discuss their structures, properties, occurrences, formations and transformations in geology and biology, including the action of iron(II)-oxidizing and iron(III)-reducing bacteria, IOB and IRB (Faivre 2016, Cornell and Schwertmann 2006, and refs herein). Articles discuss the close association of iron with biological systems, for instance in Taylor and Konhauser 2011, or Posth et al. 2018, and refs hereins). Since 2013, I show in conferences and articles that ferric compounds can form under anoxic conditions, at high $\mathrm{T} \sim 300^{\circ} \mathrm{C}-350{ }^{\circ} \mathrm{C}$, high $\mathrm{P} \sim 10 \mathrm{MPa}-25 \mathrm{MPa}$ and high $\mathrm{pH} \sim 9.5-14$. This proposition is based on a new redox equation that I extract from E-pH diagrams drawn for the system $\mathrm{Fe}-\mathrm{H}_{2} \mathrm{O}(\mathrm{Cook}$ and Olive 2012). The diagrams are posted at the URL address in Bassez (Bassez 1998-2018: La Géobiotropie). This equation which represents the oxidation of $\mathrm{Fe}^{\mathrm{II}}$ into $\mathrm{Fe}^{\mathrm{III}}$ in the absence of oxygen and with the release of $\mathrm{H}_{2}$, led to the thermodynamic studies of hydrolyses and carbonations of silicates (Bassez 2013-Bassez 2017a, b) and to the new concept of geobiotropy (Bassez 2016a, b, $2017 \mathrm{a}, \mathrm{b}$ ). The understanding that synthesis of ferric compounds from ferrous compounds can occur in anoxic conditions, opens wide areae of new interpretations of chemical processes on Earth and in the Universe. In this article I show one part of this new domain: how the alkaline anoxic abiotic oxidation of ferrous iron can bring new insights into the understanding of the Banded Iron Formations and the origin of life.

The products of the hydrolyses and carbonations of the iron-rich olivine and pyroxene silicates, fayalite and ferrosilite, are identified considering water in its high-subcritical state and silica, $\mathrm{SiO}_{2}$, solubility in its discontinuous behavior at the critical point of water. Further on, these products can dehydrate into particular amphiboles and phyllosilicates when solutions are supersaturated in $\mathrm{SiO}_{2}$ at high-subcritical conditions of water and these amphiboles and phyllosilicates are those found in the layers of BIFs.

I observe that during the interaction between water and iron containing rocks at high $\mathrm{T}$ high $\mathrm{P}$ high $\mathrm{pH}$, the rock produces electrons which are captured by water, releasing thus 
ferric iron in the absence of oxygen, and releasing also $\mathrm{H}_{2}$ which can be used in prebiotic reactions. This process of evolution of rocks and their mineral contents, which occurs in symbiosis with the synthesis of prebiotic molecules, is conceptualized within the word geobiotropy. It is a concept which differs from the concept of catalysis where minerals are recovered unchanged after the reactions. I first proposed this action of rocks as reactants and not only as catalysts in Bassez (2003): "Therefore, specific reactions might occur in particular cavities, while cavity walls might act as catalysts or reactants." This idea started to be developped in Bassez (2008, 2009a, b), considering a chemical evolution with a geological origin. Experiments were proposed with the rock peridotite as reactant. In the contrary to geobiology which is the study of how microbial processes leave imprints on rocks, geobiotropy is the study of the transformation of rocks during their interaction with water and carbonated water while leading towards the formation of prebiotic molecules. In the search for life, geobiology studies the signatures that life leaves on rocks and geobiotropy the signatures that rocks leave on themselves during their evolution towards prebiotic molecules. Prebiotic chemistry instead of life may have left its signature in the Archean era, before the Great Oxidation Event, as it is shown here for BIFs. Archean prebiotic chemistry may proceed inside the closed systems that are fluid inclusions possibly enclosed in the silica, hematite, $\mathrm{Fe}^{\mathrm{III}}$-greenalite and siderite of BIFs and/or hydrothermal terrains.

Thus, neither UV light, nor oxygen, nor sulfate-reducing bacteria, nor iron-oxidizing bacteria, nor $\mathrm{O}_{2}$-producing cyanobacteria, are necessary to explain the constituents of BIFs. Instead minerals of BIFs and/or hydrothermal rocks can form in alkaline anoxic high-subcritical water and may be at the origin of the formation of prebiotic molecules and life. The continuity from rocks to the components of life seems best illustrated by the painting of Newton that William Blake produced in the years 1795-1805 and that I interpret as the evolution from rocks to life and intelligence.

\section{Calculations and Methods of Theoretical and Experimental Analysis}

In order to demonstrate scientifically the idea of continuity from rock to life, I start with the analysis of E-pH Pourbaix diagrams drawn for corrosion purposes in 2012, by William G. Cook and Robert P. Olive, for the system Fe- $\mathrm{H}_{2} \mathrm{O}$ at high-subcritical, low-supercritical conditions, $300{ }^{\circ} \mathrm{C}-350{ }^{\circ} \mathrm{C}$, high P $10 \mathrm{MPa}-25 \mathrm{MPa}$.

A private communication with W. Cook in September 2016 confirmed the drawings. I observed that at high $\mathrm{pH}$, the redox line located between the $\mathrm{Fe}(\mathrm{OH})_{4}{ }^{-}$and $\mathrm{Fe}(\mathrm{OH})_{3}{ }^{-}$ ions is positioned below the redox line $\mathrm{H}^{+} / \mathrm{H}_{2}$. This means that the redox potential line of the $\mathrm{H}^{+} / \mathrm{H}_{2}$ couple is higher than the redox potential line of the $\mathrm{Fe}^{3+} / \mathrm{Fe}^{2+}$ couple and that the $\mathrm{H}^{+} / \mathrm{H}_{2}$ couple oxidizes the $\mathrm{Fe}^{3+} / \mathrm{Fe}^{2+}$ couple. In other words, when the $\mathrm{Fe}^{2+}$ ion or the divalent form of iron, $\mathrm{Fe}^{\mathrm{II}}$, is in contact with alkaline near supercritical water, water transforms into $\mathrm{H}_{2}$ and ferrous iron transforms into ferric iron in the absence of oxygen. This is represented by the Eq. (1) of Table 1. This redox equation is then applied to chemical equations of dissolution of rocks which contain olivine and pyroxene. Calculations of the thermodynamic functions enthalpies and free enthalpies for the endothermic and exothermic hydrolyses and carbonations of $\mathrm{Fe}^{\mathrm{II}}, \mathrm{Mg}$-silicates and $\mathrm{Fe}^{\mathrm{II}}$-monosulfides, together with the analysis of thermodynamic E-pH diagrams were reported earlier (Bassez 2013) and published in articles (Bassez 2015-2017a, b). 
The new Eq. (1) of anoxic oxidation of ferrous iron is applied here to the minerals observed in BIFs. The method consists in the observation that silica, $\mathrm{SiO}_{2}$, which is produced in the hydrolysis and carbonation of fayalite and ferrosilite, has the property of being highly soluble under the same conditions of $\mathrm{T}$ and $\mathrm{P}$ that lead to the anoxic oxidation of ferrous iron into ferric iron. The state of water considered is high-subcritical, that I write hsc. I observe a discontinuous behavior in the solubility of silica, $\mathrm{SiO}_{2}$, at the critical point of water. The solubility falls to almost zero just above the critical point and is high just below the critical point. I apply this observation to the anoxic hydrolysis and carbonation of the $\mathrm{Fe}^{\mathrm{II}}$-rich endmembers of olivine, fayalite $\mathrm{Fe}_{2}{ }_{2} \mathrm{SiO}_{4}$ and pyroxene, ferrosilite $\mathrm{Fe}^{\mathrm{II}} \mathrm{SiO}_{3}$, and to the dehydration products of greenalite, considering that the interacting water may already contain silica. The validity of the equations showing the minerals which form when water is in the high-subcritical state is discussed through several recent experiments conducted by other authors. These experiments were not reported in the earlier articles.

The proposed prebiotic chemistry inside fluid inclusions is also based on this anoxic oxidation of ferrous iron. The $\mathrm{Fe}^{\mathrm{II}}$-olivine and -pyroxene containing rocks evolve in alkaline hsc water to form $\mathrm{Fe}^{\mathrm{III}}$-oxides and -silicates together with $\mathrm{H}_{2}$ which, from a product of inorganic water-rock interaction, becomes a reactant in organic reactions.

The experimental analysis of the content in minerals and organic matter of Archean rocks is conducted with Raman spectroscopy and imaging. The instrument used is the Witec alpha300 confocal microscope operated with a green $532 \mathrm{~nm}$ laser light and located in the department of geology in the university of Johannesburg, South-Africa.

\section{Theoretical Results with Application to BIFs and Geobiotropy}

\section{High-Subcritical Anoxic Alkaline Water for the Formation of Ferric Iron and Ferric Minerals. Analyses of E-pH and Solubility Diagrams and of Published Experimental Results}

Table 1 shows the chemical equations for the anoxic formation of ferric iron (1) and the consecutive minerals that can be classified as ferric oxides/hydroxides, silica, carbonates and ferric silicates. Details of these formations are described below in connection with the minerals of the Banded Iron Formations, BIFs, which are described in detail in the next chapter.

\section{Formation of Ferric Iron in Anoxic High-Subcritical Water}

The iron hydroxides species $\mathrm{Fe}(\mathrm{OH})_{3}{ }^{-}$and $\mathrm{Fe}(\mathrm{OH})_{4}{ }^{-}$appear in the Pourbaix diagrams, published by Cook and Olive in 2012, at high-alkaline $\mathrm{pH} \sim 9.5-14$, high $\mathrm{T} 300{ }^{\circ} \mathrm{C}-350{ }^{\circ} \mathrm{C}$ and high P $10 \mathrm{MPa}-25 \mathrm{MPa}$. From these diagrams, I write the chemical Eq. (1) (Bassez 2013Bassez 2017a, b), which represents the anoxic oxidation of ferrous iron at high-subcritical (hsc) conditions of water (supercritical conditions of pure water are: $\mathrm{Tc}=374{ }^{\circ} \mathrm{C}, \mathrm{Pc}=$ 22.1 MPa). $\mathrm{Fe}^{\mathrm{II}}$ is oxidized into $\mathrm{Fe}^{\mathrm{III}}$ by loss of one electron and $\mathrm{H}_{2} \mathrm{O}$ is reduced to $1 / 2 \mathrm{H}_{2}$ by gain of one electron. While Cairns-Smith proposed that in Precambrian times, "that was the great period of ferric sedimentation in the form of ...BIFs", UV light can oxidize $\mathrm{Fe}^{\mathrm{II}}$ in acidic water (Cairns-Smith 1978), I propose that it is alkaline water near its critical point which oxidizes $\mathrm{Fe}^{\mathrm{II}}$ into $\mathrm{Fe}^{\mathrm{III}}$ and plays the role of electron-acceptor. 
Table 1 Hydrolysis/Oxidation of ferrous iron into ferric iron in anoxic alkaline high-subcritical water. Mechanism of dissolution of fayalite and ferrosilite to form hematite

\begin{tabular}{|c|c|}
\hline Chemical equations & Equ. $\mathrm{N}^{\circ}$ \\
\hline $\begin{array}{l}\text { A chemical equation for the oxidation of ferrous iron in anoxic conditions at: } \\
\qquad \begin{array}{l}\mathrm{T}=300^{\circ} \mathrm{C}-350^{\circ} \mathrm{C}, \quad \mathrm{P}=10 \mathrm{MPa}-25 \mathrm{MPa}, \quad \sim 9.5<\mathrm{pH}<14 \\
\mathrm{Fe}^{\mathrm{II}}(\mathrm{OH})_{3}{ }_{(\mathrm{dis})}+\mathrm{H}_{2} \mathrm{O}_{(\mathrm{hsc})} \rightarrow \mathrm{Fe}^{\mathrm{III}}(\mathrm{OH})_{4}{ }_{(\mathrm{dis})}+1 / 2 \mathrm{H}_{2(\mathrm{~g})}\end{array}\end{array}$ & (1) \\
\hline \multicolumn{2}{|l|}{ a) Hydrolysis and carbonation of fayalite $\mathrm{Fe}_{2} \mathrm{SiO}_{4}$ in basic hsc water } \\
\hline $\begin{array}{l}\text { Dissolution of fayalite and formation of the ferric trihydroxide anion } \\
\mathrm{Fe}_{2}{ }_{2} \mathrm{SiO}_{4(\mathrm{~s})}+\mathrm{H}_{2} \mathrm{O}_{(\mathrm{hsc})}+\mathrm{OH}^{-} \rightarrow \mathrm{Fe}^{2+}{ }_{\text {(dis) }}+\mathrm{SiO}_{2 \text { (dis) }} \rightarrow \mathrm{Fe}^{\mathrm{III}}(\mathrm{OH})_{4}^{-} \text {(dis) }+\mathrm{H}_{2(\mathrm{~g})}\end{array}$ & $(2)^{*}$ \\
\hline $\begin{array}{l}\text { Dehydration of ferric trihydroxide into goethite \& lepidocrocite } \\
\mathrm{Fe}^{\mathrm{III}} \mathrm{O}(\mathrm{OH}) \mathrm{H}_{2} \mathrm{O}_{(\mathrm{s})} \rightarrow \mathrm{H}_{2} \mathrm{O}+\mathrm{Fe}^{\mathrm{III}} \mathrm{O}(\mathrm{OH})_{(\mathrm{s})}\end{array}$ & (3) \\
\hline $\begin{array}{l}\text { Dehydration of ferric oxide hydroxide into hematite, with possibly ferrihydrite as intermediate } \\
2 \mathrm{Fe}^{\mathrm{III}} \mathrm{O}(\mathrm{OH})_{(\mathrm{s})} \rightarrow \mathrm{H}_{2} \mathrm{O}+\mathrm{Fe}^{\mathrm{III}}{ }_{2} \mathrm{O}_{3(\mathrm{~s})}\end{array}$ & (4) \\
\hline $\begin{array}{l}\text { Hydrolysis of fayalite to form hematite } \\
\mathrm{Fe}_{2}{ }_{2} \mathrm{SiO}_{4(\mathrm{~s})}+\mathrm{H}_{2} \mathrm{O}_{(\mathrm{hsc})} \rightarrow \mathrm{SiO}_{2(\text { dis })}+\mathrm{H}_{2(\mathrm{~g})}+\mathrm{Fe}^{\mathrm{III}}{ }_{2} \mathrm{O}_{3(\mathrm{~s})}\end{array}$ & (5) \\
\hline $\begin{array}{l}\text { Hydrolysis of fayalite to form } \mathrm{Fe}^{\mathrm{IIII}} \text {-greenalite } \\
\mathrm{Fe}^{2+}{ }_{\text {(dis) }}+\mathrm{Fe}^{3+}{ }_{\text {(dis) }}+\mathrm{H}_{2} \mathrm{O}_{(\mathrm{hsc})}+\mathrm{SiO}_{2 \text { (dis) }} \rightarrow \mathrm{Fe}^{\mathrm{II}} \text {, } \mathrm{Fe}^{\mathrm{III}} \text {-silica gel } \rightarrow\left(\mathrm{Fe}^{\mathrm{II}} \mathrm{Fe}^{\mathrm{III}}\right)_{2-3} \mathrm{Si}_{2} \mathrm{O}_{5}(\mathrm{OH})_{4(\mathrm{am})}=\mathrm{Fe}^{\mathrm{III}} \text {-greenalite }\end{array}$ & $(6)^{*}$ \\
\hline $\begin{array}{l}\text { Carbonation of fayalite to form siderite } \\
\mathrm{Fe}_{2} \mathrm{SiO}_{4(\mathrm{~s})}+2 \mathrm{CO}_{2 \text { (dis) }} \rightarrow 2 \mathrm{FeCO}_{3(\mathrm{~s})}+\mathrm{SiO}_{2 \text { (dis) }}\end{array}$ & (7) \\
\hline b) Hydrolysis and carbonation of ferrosilite $\mathrm{FeSiO}_{3}$ in basic hsc water (same mecha & \\
\hline $\begin{array}{l}\text { Hydrolysis of ferrosilite to form hematite } \\
\mathrm{Fe}^{\mathrm{II}} \mathrm{SiO}_{3(\mathrm{~s})}+1 / 2 \mathrm{H}_{2} \mathrm{O}_{\text {(hsc) }} \rightarrow \mathrm{SiO}_{2 \text { (dis) }}+1 / 2 \mathrm{H}_{2(\mathrm{~g})}+1 / 2 \mathrm{Fe}^{\mathrm{III}}{ }_{2} \mathrm{O}_{3(\mathrm{~s})}\end{array}$ & $(8)$ \\
\hline $\begin{array}{l}\text { Hydrolysis of ferrosilite to form } \mathrm{Fe}^{\mathrm{III}} \text {-greenalite } \\
\mathrm{Fe}^{2+}{ }_{\text {(dis) }}+\mathrm{Fe}^{3+}{ }_{\text {(dis) }}+\mathrm{H}_{2} \mathrm{O}_{(\mathrm{hsc})}+\mathrm{SiO}_{2 \text { (dis) }} \rightarrow \mathrm{Fe}^{\mathrm{II}}, \mathrm{Fe}^{\mathrm{III}} \text {-silica gel } \rightarrow\left(\mathrm{Fe}^{\mathrm{II}} \mathrm{Fe}^{\mathrm{III}}\right)_{2-3} \mathrm{Si}_{2} \mathrm{O}_{5}(\mathrm{OH})_{4(\mathrm{am})}=\mathrm{Fe}^{\mathrm{III}} \text {-greenalite }\end{array}$ & $(6)^{*}$ \\
\hline $\begin{array}{l}\text { Carbonation of ferrosilite to form siderite } \\
\mathrm{FeSiO}_{3(\mathrm{~s})}+\mathrm{CO}_{2 \text { (dis) }} \rightarrow \mathrm{FeCO}_{3(\mathrm{~s})}+\mathrm{SiO}_{2 \text { (dis) }}\end{array}$ & (9) \\
\hline
\end{tabular}

$\mathrm{FeSiO}_{3(\mathrm{~s})}+\mathrm{CO}_{2(\mathrm{dis})} \rightarrow \mathrm{FeCO}_{3(\mathrm{~s})}+\mathrm{SiO}_{2(\text { dis })}$

c) Dehydration of $\mathrm{Fe}^{\mathrm{III}}$-greenalite into $\mathrm{Fe}^{\mathrm{III}}$-minnesotaite in a solution supersaturated in silica

$\left(\mathrm{Fe}^{\mathrm{II}} \mathrm{Fe}^{\mathrm{III}}\right)_{2-3} \mathrm{Si}_{2} \mathrm{O}_{5}(\mathrm{OH})_{4(\mathrm{am})}+2 \mathrm{SiO}_{2(\mathrm{dis})} \rightarrow\left(\mathrm{Fe}^{\mathrm{II}} \mathrm{Fe}^{\mathrm{III}}\right)_{2-3} \mathrm{Si}_{4} \mathrm{O}_{10}(\mathrm{OH})_{2}+\mathrm{H}_{2} \mathrm{O}_{(\mathrm{hsc})}$

$$
\Delta_{\mathrm{r}} \mathrm{H}^{0}=+13.61 \mathrm{~kJ} \cdot \mathrm{mol}^{-1} ; \Delta_{\mathrm{r}} \mathrm{G}^{0}=+3.71 \mathrm{~kJ} \cdot \mathrm{mol}^{-1} \quad(10)
$$

*The mechanisms of dissolution of fayalite is shown in the non-equilibrated reaction (2). The product $\mathrm{Fe}^{\text {III- }}$-greenalite is written in the non-equilibrated reaction (6), with the intermediate silica-gel proposed in Tosca et al. 2016. Enthalpies $\Delta_{\mathrm{r}} \mathrm{H}^{0}$ and free enthalpies $\Delta_{\mathrm{r}} \mathrm{G}^{0}$ are calculated with the 1995 Robie and Hemingway $25^{\circ} \mathrm{C}$ data, as in Bassez $(2017 \mathrm{a}, \mathrm{b})$ where all values of $\Delta_{\mathrm{r}} \mathrm{H}^{0}$ and $\Delta_{\mathrm{r}} \mathrm{G}^{0}$ are calculated. Values of $\Delta_{\mathrm{f}} \mathrm{H}^{0}$ and $\Delta_{\mathrm{f}} \mathrm{G}^{0}$ for greenalite and minnesotaite are from the Thermoddem, BRGM data base. hsc = high-subcritical

\section{Dissolution of Fayalite and Formation of Dissolved $\mathrm{Fe}^{2+}$}

As a consequence of Eq. (1), the ferrous iron of fayalite and ferrosilite should oxidize in anoxic alkaline subcritical water to form the dissolved ferric species $\mathrm{Fe}(\mathrm{OH})_{3} \mathrm{OH}^{-}$. However, Fig. 4 in Cook and Olive (2012) shows that the $\mathrm{pH}$ of water is acidic at high-subcritical T\&P (5.8 at $350{ }^{\circ} \mathrm{C} \& 25 \mathrm{MPa}, 5.6$ at $350{ }^{\circ} \mathrm{C} \& 50 \mathrm{MPa}$ ) and that it increases highly in the supercritical state $\left(9.8\right.$ at $540{ }^{\circ} \mathrm{C} \& 25 \mathrm{MPa}, 7.4$ at $\left.540{ }^{\circ} \mathrm{C} \& 50 \mathrm{MPa}\right)$. Thus, pH-controlling reagents need to be present to make hsc water alkaline, for instance ammonium hydroxide which produces pH 10.6 at $25^{\circ} \mathrm{C}$ in a $0.01 \mathrm{~N}$ solution (PubChem 2018) and which could be locally outgassing from the Earth's interior in Archean times. However, at the T\&P of hsc water, ammonia is in the supercritical, $\mathrm{sc}$, state $\left(\mathrm{Tc}=132{ }^{\circ} \mathrm{C}, 11.33 \mathrm{MPa}\right)$ with a structure where the intermolecular hydrogen bonds of the liquid "are strongly attenuated" (Tassaing et al. 2010). Therefore $\mathrm{pH}$ values should be different than those in liquid ammonium hydroxide aqueous solutions at 
$25^{\circ} \mathrm{C}$. Nonetheless, sc ammonia can most probably associate with $\mathrm{Fe}^{2+}$ to form complexes which may drive the dissolution of fayalite. Indeed, the kinetics of fayalite dissolution in water was studied at acid $\mathrm{pH} 1.11-2.70,30 \mathrm{MPa}$ and $50{ }^{\circ} \mathrm{C}$ to $100{ }^{\circ} \mathrm{C}$ by Daval et al. (2010) who propose that "as for many other minerals, organic ligands are able to promote the dissolution of fayalite via surface complexation" and that $\mathrm{Fe}^{2+}$ can associate with two acetate ligands to form $\mathrm{Fe}\left(\mathrm{CH}_{3} \mathrm{COO}\right)_{2} \cdot 4 \mathrm{H}_{2} \mathrm{O}$. "This solvation ...would explain the observed enhancement of the dissolution rate". In alkaline solutions, the $\mathrm{Fe}(\mathrm{II})$-ammonia complex $\mathrm{Fe}\left(\mathrm{NH}_{3}\right)_{\mathrm{a}}{ }^{2+}(\mathrm{a}=1,2)$ is known to exist and also the hydroxoamminocomplex $\mathrm{Fe}(\mathrm{OH})_{\mathrm{n}}\left(\mathrm{NH}_{3}\right)_{\mathrm{a}}{ }^{(2-\mathrm{n})+}(n=1,2,3)$ (Ziemniak et al. 1995 and ref. herein). Thus, ammonia in hsc water should lead to alkaline $\mathrm{pH}$ and $\mathrm{Fe}^{\mathrm{II}}$-ammonia complexes which help the dissolution of fayalite.

KOH could also set alkaline pH. For example, Fig. 24 in Macdonald et al. (1992) shows that a solution of $0.01 \mathrm{M} \mathrm{KOH}$ produces $\mathrm{pH} \sim 9$ at $275^{\circ} \mathrm{C}$ and $\sim 9.5$ at $374{ }^{\circ} \mathrm{C}$. However, the best candidate for basic and ultrabasic water is $\mathrm{NaOH}$ as observed in samples from springs issuing from ultramafic rocks in California and Oregon (Barnes et al. 1967) where "waters of two chemically distinctive types are found." The huge difference between the moderately alkaline water $(\mathrm{pH} \mathrm{8.3-8.6)}$ and the ultrabasic water $(\mathrm{pH} 11.2-11.8)$ is the abundance of $\mathrm{Na}^{+}$which is up to $\sim 60$ times higher in the ultrabasic water. $\mathrm{NaOH}$ could arise from the dissolution of the mineral disodium carbonate named natrite $\mathrm{Na}_{2} \mathrm{CO}_{3}$ (Khomyakov 1983; Arakcheeva et al. 2010) which forms strongly alkaline aqueous solutions. At $25{ }^{\circ} \mathrm{C}$, a solution of $\mathrm{Na}_{2} \mathrm{CO}_{3}, 1 \mathrm{wt} \%$, has a pH of 11.37 (PubChem 2018). Other carbonates can be envisioned: thermonatrite $\mathrm{Na}_{2} \mathrm{CO}_{3} \cdot \mathrm{H}_{2} \mathrm{O}$, natron $\mathrm{Na}_{2} \mathrm{CO}_{3} \cdot 10 \mathrm{H}_{2} \mathrm{O}$ and also dipotassium carbonate $\mathrm{K}_{2} \mathrm{CO}_{3}$. I am currently studying modern analogs of alkaline waters which are found in basic or soda lakes. For instance, the lake Magadi in Kenya shows $\mathrm{pH} 9$ and large deposits of trona $\mathrm{NaCO}_{3} \cdot \mathrm{NaHCO}_{3} \cdot 2 \mathrm{H}_{2} \mathrm{O}$ and sodium-aluminium silicate gels (Eugster and Jones 1968).

The dissolution of fayalite in hsc water should also be induced considering the solubilities of amorphous and crystalline silica which both increase with $\mathrm{T}$ and $\mathrm{P}$ apart from an exception at the critical point of water as shown below in the paragraph on silica. In hsc water, both amorphous and crystalline silica dissolve in equal amounts. Thus, fayalite should dissolve easily in hscw conditions. In extra, the more fayalite dissolves, the more goethite forms and the more silica is adsorbed on goethite (Siever and Woodford 1973; Sigg and Stumm 1981), inducing more dissolution of fayalite. The same process of adsorption is observed when a silica-rich layer covers a hematite nanocrystal core, as shown in Fig. 6 of the experiment conducted by Qafoku et al. (2012) which is described below in the section on Related Laboratory Experiments of the present chapter. The effect of hydrolysis of fayalite to form goethite, hematite and silica is combined to the adsorption of silica on goethite and hematite which decreases the concentration of silica in solution, and consequently further promotes fayalite dissolution. Fayalite should dissolve until silica saturation is achieved, as confirmed by the experiment conducted by Karasek et al. (2013a) on fused silica capillaries, described below in the section on Dissolution of Silica of the present chapter.

Therefore, some local environmental conditions of T, $\mathrm{P}, \mathrm{pH}$ and composition of hsc water may combine in order that fayalite \& ferrosilite dissolve in alkaline high-subcritical water. The observation of the dissolution of fayalite in supercritical $\mathrm{CO}_{2}$ (Qafoku et al. 2012) is described below in the section on laboratory experiments.

\section{Formation of Iron Oxides Hydroxides}

Following the dissolution of fayalite, the $\mathrm{Fe}(\mathrm{OH})_{3} \mathrm{OH}^{-}$species can form. $\mathrm{Fe}(\mathrm{OH})_{3} \mathrm{OH}^{-}$is the anion form of ferric trihydroxide $\mathrm{Fe}(\mathrm{OH})_{3}$, which can be written as $\mathrm{FeO}(\mathrm{OH}) \mathrm{H}_{2} \mathrm{O}$, which can dehydrate into the ferric oxide hydroxides $\alpha$ - and $\gamma$ - $\mathrm{FeO}(\mathrm{OH})$ named respectively goethite 
and lepidocrocite (Eq. 3), and into the ferric oxide hematite $\alpha-\mathrm{Fe}_{2} \mathrm{O}_{3}$ (Eq. 4). Magnetite $\mathrm{Fe}_{3} \mathrm{O}_{4}$ is a secondary product which forms at $\sim 400^{\circ} \mathrm{C}$ and above as described in Bassez $2017 \mathrm{~b}$ on the basis of published experiments. Other experiments show that magnetite can be produced from siderite such as in siderite decomposition at $\mathrm{T} \sim 450^{\circ} \mathrm{C} 50 \mathrm{MPa}$ (French and Rosenberg 1965) or siderite hydrolysis with release of $\mathrm{H}_{2}$ at $300{ }^{\circ} \mathrm{C}, 50 \mathrm{MPa}$ (Milesi et al. 2015).

The plausible dehydration of iron hydroxides into iron oxides is reinforced by the observations made by Adschiri and co-workers between 1992 and 2001, that "fine metal oxide particles form when metal nitrates are contacted with supercritical water in a flow system." The authors "postulated" that "the fine particles were produced because supercritical water causes the metal hydroxides to rapidly dehydrate before significant growth takes place... Processing in Scw increases the rate of dehydration." (Byrappa and Adschiri 2007 p.136 and refs herein). In these experiments, hematite particles formed at $400{ }^{\circ} \mathrm{C}, 35 \mathrm{MPa}$ with high dehydration rates. They were spherical and $\sim 20$ to $\sim 50 \mathrm{~nm}$ in size. "We think the high reaction rates obtained in this experiment are due to the elevated reaction temperature, the high diffusivity of the reactants in supercritical water, and the fast dehydration reaction of the fine hydrous oxide particles." (Adschiri et al. 1992). In these experiments, the dehydration of iron oxide hydroxides into oxides occurs in supercritical water. However, the properties of highsubcritical water approaching those of low supercritical water (Cook and Olive 2012) it is most probable that oxides form also from oxide hydroxides at subcritical conditions.

The intermediate poorly ordered ferrihydrite $\mathrm{Fe}_{5} \mathrm{HO}_{8} \cdot 4 \mathrm{H}_{2} \mathrm{O}$ can also form prior to final hematite, $\alpha-\mathrm{Fe}_{2} \mathrm{O}_{3}$ as experimentally demonstrated in Rzepa et al. (2016) where the transformation of ferrihydrite to hematite is observed at $300-350{ }^{\circ} \mathrm{C}$.

Therefore, high-subcritical water allows the formation of ferric iron in anoxic conditions and also increases the rates of formation of hematite from goethite and lepidocrocite, with an intermediate compound which can be ferrihydrite. As it is described in the chapter on Banded Iron Formations, hematite can be a primary product, in this proposed process of formation.

\section{Formation of $\mathrm{Fe}^{I I I}$-Silicates}

The silicate greenalite $\mathrm{Fe}_{3}{ }_{3} \mathrm{Si}_{2} \mathrm{O}_{5}(\mathrm{OH})_{4}$ is the iron equivalent of the serpentine chrysotile, $\mathrm{Mg}_{3} \mathrm{Si}_{2} \mathrm{O}_{5}(\mathrm{OH})_{4}$, which forms by the action of water on the Mg-endmembers of olivine and pyroxene with production of brucite $\mathrm{Mg}(\mathrm{OH})_{2}$ (Bassez 2017a\&b). However, Eq. (6) is written here, not by analogy with the formation of chrysotile, but considering the structures which are experimentally observed when dissolved $\mathrm{Fe}^{2+}$ is mixed with silica $\mathrm{SiO}_{2}$ in anoxic aqueous solutions at $25^{\circ} \mathrm{C}$. The formation of a Fe(II)-silicate gel is observed. Tosca et al. (2016) describe a "hydrated, disordered Fe-silicate "gel" phase...Subsequent dehydration and structural rearrangement within the gel phase lead to the formation of nanoparticle domains that exhibit shortrange order...producing the structure of greenalite". In 1998, Guggenheim and Eggleton observed with Transmission Electron Microscopy that greenalite is a modulated 1:1 phyllosilicate: "the octahedrally coordinated Fe...form trioctahedral sheets. Six-member rings of tetrahedra link to form triangular islands...The tetrahedra show limited short-range order...but long-range disorder. Linkages of tetrahedra between islands are apparently complety disordered." Diagrams for the activity of $\mathrm{Fe}^{2+}$ as a function of $\mathrm{pH}$, drawn at $25^{\circ} \mathrm{C}$ (Fig.12 in Tosca et al. 2016, show that greenalite starts to nucleate at $\mathrm{pH} 9$ in a much lower content of dissolved $\mathrm{Fe}^{2+}$ than at $\mathrm{pH}$ 7. Thus, greenalite can nucleate in alkaline solutions containing a small amount of $\mathrm{Fe}^{2+}$.

As described in Bassez 2017a \& b, chrysotile can form as $\left(\mathrm{Mg}, \mathrm{Fe}^{\mathrm{II}}\right)_{3} \mathrm{Si}_{2} \mathrm{O}_{5}(\mathrm{OH})_{4}$ or $\left(\mathrm{Al}, \mathrm{Fe}^{\mathrm{III}}\right)_{2} \mathrm{Si}_{2} \mathrm{O}_{5}(\mathrm{OH})_{4}$, thus incorporating the ferric iron which is produced in anoxic alkaline 
hsc water. In the same process, greenalite can incorporate $\mathrm{Fe}^{\mathrm{III}}$ to form $\left(\mathrm{Fe}^{\mathrm{II}}, \mathrm{Fe}^{\mathrm{III}}\right)_{2}$ ${ }_{3} \mathrm{Si}_{2} \mathrm{O}_{5}(\mathrm{OH})_{4}$ and cronstedtite can also form as $\mathrm{Fe}_{2}^{\mathrm{II}}{ }_{2} \mathrm{Fe}^{\mathrm{III}}\left(\mathrm{SiFe}^{\mathrm{III}}\right) \mathrm{O}_{5}(\mathrm{OH})_{4}$. Chrysotile, greenalite and cronstedtite belong all three to the serpentine group. $\mathrm{Fe}^{\mathrm{III}}$-greenalite synthesized in alkaline hsc water can thus be a primary product in BIFs. This chemical process of greenalite formation finds confirmation in the very recent microscopic and spectroscopic observations of nanoparticle-bearing samples from $\sim 2.5 \mathrm{Ga}$ BIFs and ferruginous cherts hosted in well-preserved cores from Western Australia and South Africa (Johnson et al. 2018). They conclude that greenalite contains $10-20 \% \mathrm{Fe}$ (III) and should be considered as a primary mineral of the BIFs.

Other silicates can also form as primary minerals of BIFs. Indeed, chrysotile dehydrates into talc $\mathrm{Mg}_{3} \mathrm{Si}_{4} \mathrm{O}_{10}(\mathrm{OH})_{2}$ when the solution is supersaturated in $\mathrm{SiO}_{2}$. As chrysotile, greenalite can dehydrate, when in a solution supersaturated in $\mathrm{SiO}_{2}$, into minnesotaite $\mathrm{Fe}_{3}{ }_{3} \mathrm{Si}_{4} \mathrm{O}_{10}(\mathrm{OH})_{2}$ or $\left(\mathrm{Fe}^{\mathrm{II}}, \mathrm{Fe}^{\mathrm{III}}\right)_{2-3} \mathrm{Si}_{4} \mathrm{O}_{10}(\mathrm{OH})_{2}$ which is the iron-rich talc, following Eq. (10). Dehydration of greenalite is calculated here to be slightly endothermic. It can proceed easily in subcritical water. Thus, minnesotaite can form as a primary product in hsc water supersaturated in silica. Since both reactions of hydrolysis and carbonation of fayalite produce silica and that the solubility of silica is high in hsc water, hsc water can be supersaturated in silica, inducing easily the synthesis of minnesotaite.

Further dehydration of greenalite can most probably lead to riebeckite and stilpnomelane. Indeed, the sodium iron silicates hydroxides of the amphibole group, riebeckite $\mathrm{Na}_{2}\left(\mathrm{Fe}_{3}{ }_{3}, \mathrm{Fe}^{\mathrm{III}}{ }_{2}\right) \mathrm{Si}_{8} \mathrm{O}_{22}(\mathrm{OH})_{2}$, grünerite $\mathrm{Fe}_{7}{ }_{7} \mathrm{Si}_{8} \mathrm{O}_{22}(\mathrm{OH})_{2}$, and the potassium iron magnesium silicate oxide hydroxide stilpnomelane which forms a series of phyllosilicates with the formula $\mathrm{K}\left(\mathrm{Fe}^{\mathrm{II}}, \mathrm{Mg}, \mathrm{Fe}^{\mathrm{III}}\right)_{8}(\mathrm{Si}, \mathrm{Al})_{12}(\mathrm{O}, \mathrm{OH})_{27} \cdot \mathrm{n}\left(\mathrm{H}_{2} \mathrm{O}\right)$ as reported in Haugaard et al. 2016, comprise much less hydroxide $(-\mathrm{OH})$ groups than minnesotaite. To my knowledge, they can thus be considered as highly dehydrated products of greenalite which form most probably in aqueous solutions supersaturated in silica. The experiment of Tosca et al. (2016) mixing $\mathrm{Fe}^{2+}$ and $\mathrm{SiO}_{2}$ was conducted at $25^{\circ} \mathrm{C}$. It seems most interesting to conduct the same kind of experiment in alkaline high-subcritical water with high level of silica, and observe if the hydrated disordered Fe-silicate gel structurally transforms into stilpnomelane when alkalinity is controlled by $\mathrm{KOH}$ and into riebeckite when alkalinity is controlled by $\mathrm{NaOH}$. As greenalite and minnesotaite, stilpnomelane and riebeckite could also incorporate $\mathrm{Fe}^{\mathrm{III}}$ in their structures, since they would form first in alkaline hsc water (conditions for formation of $\mathrm{Fe}^{\mathrm{III}}$ ) and second from dehydrated $\mathrm{Fe}^{\mathrm{II}}, \mathrm{Fe}^{\mathrm{III}}$-greenalite.

Therefore, the silicates greenalite, minnesotaite, cronstedtite, riebeckite and stilpnomelane may form following the hydrolysis/oxidation of ferrous iron in anoxic alkaline high-subcritical water and contain the ferric iron $\mathrm{Fe}^{\mathrm{III}}$.

\section{Formation of Carbonates}

The diagram drawn for the activity of $\mathrm{Fe}^{2+}$ as a function of $\mathrm{pH}$ (Fig.14 in Eugster and Chou 1973) shows that the solubility of siderite is very low at $\mathrm{pH} 9$ to 14 at $25^{\circ} \mathrm{C}$. Bénézeth et al. (2009) studying the effect of temperature at $\mathrm{pH} \sim 6$, showed a decrease of the solubility product of siderite from $25^{\circ} \mathrm{C}$ to $250{ }^{\circ} \mathrm{C}$.

Therefore, it appears that siderite precipitates when $\mathrm{T}$ increases and at alkaline $\mathrm{pH}$. It is possible to advance that at hsc water and high $\mathrm{pH}$, siderite forms and precipitates easily. The formation of siderite trough the hydrolysis of fayalite is an exothermic process (Bassez 2017a, b) which does not depend on $\mathrm{pH}$ and $\mathrm{T}$ as much as the formation of $\mathrm{Fe}^{\mathrm{III}}$. Therefore, long lengths of siderite without ferric oxides neither silicates may be observed. 


\section{Dissolution of Silica}

The solubilities of crystalline and amorphous silica in water have been widely experimentally and theoretically studied. Diagrams show that both solubilities increase with $\mathrm{pH}$, and T\&P apart from an exception at the critical point of water, as described below:

Solubility of Amorphous Silica Versus Quartz. Fournier and Rowe (1977) show that amorphous silica dissolves in greater amount than quartz from $25^{\circ} \mathrm{C}$ up to the critical point of water. Williams and Crerar (1985) report the same trend in their Fig.1b (upon Walther and Helgeson 1977) with a difference in solubilities which seems to decrease at $350{ }^{\circ} \mathrm{C}$. Karasek et al. (2013a) show in their Fig.4 that the solubility ratio of amorphous silica to quartz decreases from $\sim 18$ at $25{ }^{\circ} \mathrm{C}$ to $\sim 2$ at $380{ }^{\circ} \mathrm{C}$.

Therefore, I conclude that at high-subcritical conditions of water $\mathrm{SiO}_{2}$ dissolves in about equal amount of amorphous and crystalline quartz and that with decreasing temperature, a larger amount of dissolved $\mathrm{SiO}_{2}$ stays in the amorphous state.

With the perspective of the scenario developed for the formation of BIFs in the next chapter, it seems interesting to consider here an earlier study at $25{ }^{\circ} \mathrm{C}$ on the progressive diagenesis of silica deposits during burial (Williams et al. 1985 and refs herein). They consider silica deposits as an "amorphous silica (opal-A)" phase which transforms upon the diagenetic sequence opal-A $\rightarrow$ opal-CT $\rightarrow$ quartz. Their Fig.6 shows the progression of diagenetic zones in a sedimentary-rock stratigraphic column. First, deposits of diatom and radiolarian tests show amorphous (opal-A) silica polymorphs which are metastable and transform upon burial: " $a$ less soluble disordered cristobalite-tridymite phase (opal-CT) forms...The opal-CT then recrystallizes to still less soluble quartz...Similar textures are observed in the opal- $A \rightarrow$ opal-CT transformation in petrified wood (Stein 1982), and in hydrothermal studies of amorphous silica, silica sols, and gels..." Williams et al. describe the aqueous solubility of the three silica species paralleling the diagenetic sequence with at $25{ }^{\circ} \mathrm{C}, \sim 60-130 \mathrm{ppm}$ for amorphous silica, $\sim 20-30 \mathrm{ppm}$ for cristobalite and $\sim 6-10 \mathrm{ppm}$ for quartz, and they describe the relative dissolution rates following the same order at $25{ }^{\circ} \mathrm{C}$ and $\mathrm{pH} 8.5$. This 1985 description of higher solubility of amorphous silica than quartz at $25{ }^{\circ} \mathrm{C}$ is confirmed in the above 2013a description of Karasek et al.

Solubilities of Amorphous Silica and Quartz as a Function of T\&P Fournier and Rowe (1977) and Williams and Crerar (1985) in their Fig.1b show that both solubilities increase with T with a turn-over at water Tc and that they increase also with P. With the 3-D diagram of Fig.3 in Karasek et al. (2013a) it appears clearly that the aqueous solubility of amorphous silica increases continuously with T\&P with a turn-over at the critical point of water. This discontinuity in solubility was already reported in several earlier articles. For instance, the solubility of quartz in neutral water was calculated up to $800{ }^{\circ} \mathrm{C}$ and $2000 \mathrm{MPa}$ (Smith Jr and Fang 2011). Their Fig.2 shows an abrupt change at the critical point of water and below $100 \mathrm{MPa}$. "At a constant pressure of $23 \mathrm{MPa}$, the $\mathrm{SiO}_{2}$ solubility increases to a value of $0.087 \mathrm{wt} \%$ at $350{ }^{\circ} \mathrm{C}$ and drastically decreases to $0.0081 \mathrm{wt} \%$ at $450{ }^{\circ} \mathrm{C}$. This behavior was already specified by Shock et al. (Fig. 14, 1989) and Manning (Fig. 6, Manning 1994), through compilations of experimental results. The abrupt change can probably be explained by the change in the dielectric constant of supercritical water (Liebscher 2010 and refs herein) and the fact that non-polar supercritical water contains non-polar water dimers (Bassez 2003) which do no dissolve ion species. 
This dissolution of silica in high-subcritical water is confirmed in an experiment conducted on fused silica capillaries, FSC, of $7 \mathrm{~cm}$ long, $500 \mu \mathrm{m}$ internal diameter, exposed to supercritical water, scw, (Karasek et al. 2013b). At $40 \mathrm{MPa}$, during an increase of temperature between $250^{\circ} \mathrm{C}$ and $400{ }^{\circ} \mathrm{C}$, the external "surface becomes progressively more coarse-grained indicating the increasing ability of water to corrode the silica surface", while " $a$ 4-h treatment with stagnant $S C W$ at $400^{\circ} \mathrm{C}$ and 400 bar did not produce any apparent effect on the inner surface." Thus, I conclude that in high-subcritical water, silica dissolves and in low supercritical water silica does not dissolve.

Therefore, the solubilities of amorphous and crystalline silica increase with $\mathrm{T}$ and $\mathrm{P}$ from $25{ }^{\circ} \mathrm{C}$ up to the critical point where a drastic decrease operates. They are high in highsubcritical water and decrease abruptly in supercritical water, below $100 \mathrm{MPa}$.

Solubilities of Amorphous Silica and Quartz as a Function of $p H$ The solubility of silica as a function of $\mathrm{pH}$ is also studied. Fig.1a in Williams and Crerar (1985) after Volosov et al. (1972) shows at $25{ }^{\circ} \mathrm{C}$ for $\mathrm{pH}<\sim 9$, the monomeric silicic weak acid $\mathrm{H}_{4} \mathrm{SiO}_{4}$, which is the predominant aqueous species in undersaturated silica solutions, for $\mathrm{pH} \sim 9-13$ the $\mathrm{H}_{3} \mathrm{SiO}_{4}{ }^{-}$ species and for $\mathrm{pH}>\sim 13$ the $\mathrm{H}_{2} \mathrm{SiO}_{4}{ }^{2-}$ species. This diagram indicates a drastic increase in the silica solubility above $\mathrm{pH}$ 9. Also, at $\mathrm{pH}>\sim 9$ the polymeric species $\mathrm{Si}_{4} \mathrm{O}_{6}(\mathrm{OH})_{6}{ }^{2-}$ forms (Williams et al. 1985 and refs herein; Baes Jr and Mesmer 1976).

When dry amorphous silica is dissolved at $250{ }^{\circ} \mathrm{C}-300{ }^{\circ} \mathrm{C}$ in a Parr minireactor and quenched at $70{ }^{\circ} \mathrm{C}$, nanoscale $\alpha$-quartz precipitate with an average size of $18 \mathrm{~nm}$. Same results were obtained with fumed silica and amorphous colloidal silica. The value of $\mathrm{pH}$ was maintained at $\sim 8$ because "more basic solutions will favor the dissolution of solid phases of silica"... "Lower temperatures and more neutral pH conditions result in unreacted amorphous product, the formation of cristobalite, or complex silicate phases...Quenched products contain significant fractions of amorphous silica." (Bertone et al. 2003 and refs herein).

Therefore, as the solution of silica $\left(\mathrm{SiO}_{2}\right)$ in polar water becomes more alkaline, the solubility of silica increases, and when amorphous silica is dissolved at $250{ }^{\circ} \mathrm{C}-300{ }^{\circ} \mathrm{C}$ and then quenched at $70{ }^{\circ} \mathrm{C}, \alpha$-quartz precipitates with incorporation of amorphous silica.

Conclusion on the Mineral Syntheses In the scenario for the formation of BIFs, upon the experiments described in the above paragraphs on Solubilities of Amorphous Silica and Quartz as a function of $T \& P$, amorphous silica and quartz dissolve in hsc water and not in low supercritical water. Considering the studies reported in the paragraphs on the Solubility of Amorphous Silica versus Quartz, the silica which is dissolved in hsc water, interacts with the ocean cool water in a quenching process, and is distributed in equal amounts of amorphous and crystalline quartz. The amorphous silica transforms further on, upon the diagenetic sequence opal-A $\rightarrow$ opal-CT $\rightarrow$ quartz, depending on the burial depth and the interaction with meteoric water, until the formation of $\alpha$-quartz. This crystalline form of quartz can differ from the crystalline quartz which formed in hsc water, thus leading to two different quartz grains in BIFs.

However, upon the Bertone experiment described in the paragraphs on Solubilities of Amorphous Silica and Quartz as a function of $\mathrm{pH}$, the quenching process in the cool ocean waters which can be around $70^{\circ} \mathrm{C}$, should lead to nanoscale $\alpha$-quartz with an amount of amorphous silica which depends on the solution $\mathrm{pH}$, more neutral $\mathrm{pH}$ producing more amorphous silica.

As a consequence of these paragraphs on silica, in alkaline high-subcritical water, silicaundersaturated water should trigger the hydrolysis and carbonation of fayalite/ferrosilite leading to the described minerals. 


\section{Related Laboratory Experiments}

Equations of Table 1 are proven in some laboratory experiments that were reported in Bassez 2017b. Below are reported other experiments connected to these equations. For instance, a very recent article (Alonso-Domínguez et al. 2017) demonstrates in a laboratory experiment analyzed with X-ray diffraction, XRD, that the nanoparticulated spinel-type iron oxides magnetite and maghemite $\gamma-\mathrm{Fe}_{2} \mathrm{O}_{3}$ crystallize in supercritical water at $450{ }^{\circ} \mathrm{C}$ and $25 \mathrm{MPa}$, while oxide hydroxides and hematite $\alpha-\mathrm{Fe}_{2} \mathrm{O}_{3}$ crystallize at lower temperature $200{ }^{\circ} \mathrm{C}$ and $380{ }^{\circ} \mathrm{C}$. This experimental result is in agreement with the differential scanning calorimetry, DSC, experiment conducted up to $685{ }^{\circ} \mathrm{C}$ (Dekkers 1990), where natural goethite, with $\sim 13 \%$ $\mathrm{H}_{2} \mathrm{O}$ attached to $\mathrm{FeO}(\mathrm{OH})$ and no titanomagnetite neither pyrrhotite but perhaps trace amounts of organic matter, converts into hematite between $260{ }^{\circ} \mathrm{C}$ and $360{ }^{\circ} \mathrm{C}$ with trace amounts of magnetite above $400{ }^{\circ} \mathrm{C}$. "At $685^{\circ} \mathrm{C}$, the magnetic mineralogy was usually dominated by magnetite". Thus, it appears that goethite and hematite form at high-subcritical conditions of water and magnetite at $400{ }^{\circ} \mathrm{C}$ and above.

Equation 7 in Table 1 can also be recognized in an experiment, conducted on the dissolution of natural occuring fayalitic olivine (Qafoku et al. 2012). The presence in the unreacted olivine of the amphiboles cummingtonite $(\mathrm{Mg}, \mathrm{Fe}, \mathrm{Mn})_{7} \mathrm{Si}_{8} \mathrm{O}_{22}(\mathrm{OH})_{2}$ and protoferro-anthophyllite ( Fe, Mn, $\mathrm{Mg})_{2} \mathrm{Fe}_{5} \mathrm{Si}_{8} \mathrm{O}_{22}(\mathrm{OH})_{2}$ is identified by X-ray diffraction. And it is reported that these two amphiboles were "unreactive under all experimental conditions". The transmission Mössbauer spectrum shows $\sim 90 \%$ of the total $\mathrm{Fe}$ associated with fayalite, $\sim 3 \%$ with magnetite and $\sim 7 \%$ with $\mathrm{Fe}^{\mathrm{III}}$-oxide. The dissolution of fayalite was studied up to 85 days at $35{ }^{\circ} \mathrm{C}$, $50{ }^{\circ} \mathrm{C}, 80^{\circ} \mathrm{C}, 9 \mathrm{MPa}$ and anoxic conditions, both in a two-phases liquid water $\mathrm{scCO}_{2}$ system, and in $\mathrm{H}_{2} \mathrm{O}$-saturated $\mathrm{scCO}_{2}$. The supercritical state of $\mathrm{CO}_{2}$ starts at $\mathrm{Tc}=31.1{ }^{\circ} \mathrm{C}$ and $\mathrm{Pc}=$ 7.38 MPa. At all temperatures, in the presence of liquid water and $\mathrm{scCO}_{2}, \mathrm{SEM}$ images of the reacted fayalite show $2-10 \mu \mathrm{m}$ rhombohedral crystals attributed to siderite ((Fig.3abc in Qafoku et al. 2012). "The lack of any clear relationship between the particle morphology and the fayalite surface indicates non-epitaxial growth of siderite...and growth in solution possible."

The particles that I observe on the SEM images of the 7-days reacted fayalite at $80{ }^{\circ} \mathrm{C}$ in liquid water $\mathrm{scCO}_{2}$ (Fig.3a in Qafoku et al. 2012) appear bigger and more regular $(5-10 \mu \mathrm{m})$ than those observed on the SEM images of the 7-days reacted fayalite at $80{ }^{\circ} \mathrm{C}$ in $\mathrm{H}_{2} \mathrm{O}-$ saturated $\mathrm{scCO}_{2}$ (Fig.4 in Qafoku et al. 2012). The Mössbauer analysis of these two types of reacted fayalite shows identical spectra, fitted with $3 \%$ siderite. Thus, the synthesis of welldefined crystals of siderite appears to require a liquid water phase. This process of carbonation seems to start at temperature as low as $35^{\circ} \mathrm{C}$ at $9 \mathrm{MPa}$ in the presence of water. This formation complies with Eq. (7) which is calculated exothermic and spontaneous at low-T in Bassez (2013-2017). It shows also the necessity of the interconnected equations of hydrolyses and carbonations of Table 1 since $\mathrm{CO}_{2}$ needs to be in contact with liquid water.

When the $80{ }^{\circ} \mathrm{C}$ dissolution of fayalite in $\mathrm{H}_{2} \mathrm{O}$-saturated $\mathrm{scCO}_{2}$, is extended to 43 days, the SEM images of the fayalite surface show $\sim 500 \mathrm{~nm}$ needle-like precipitates in platelet-like morphology (Fig.6 in Qafoku et al. 2012). TEM analysis concluded in a hematite nanocrystal core covered with a silica-rich layer. "An increase in reddish appearance" is observed. TEMselected area electron diffraction, TEM-SAED, analysis conducted underneath the hematite platelets show two separate crystalline phases of siderite and fayalite with no crystallographic relationship and $\sim 10$ to $20 \mu \mathrm{m}$ siderite vertical growths composed of rythmic horizontal layers with a 3 to $4 \mu \mathrm{m}$ "rhombus morphology at the base". As mentionned by Qafoku et al. 2012, 
"formation of water film, necessary for siderite growth to occur, has been reported to take place at nanometer thickness at the forsterite surface under $\mathrm{H}_{2} \mathrm{O}$-saturated $\mathrm{scCO}_{2}$ environments (Loring et al. 2012). We speculate that such film formation can also occur on fayalite...".

Thus, in experimental conditions far from the critical point of water, at $80{ }^{\circ} \mathrm{C}$ and $9 \mathrm{MPa}$, and in $\mathrm{H}_{2} \mathrm{O}$-saturated $\mathrm{scCO}_{2}$, in other words in supercritical $\mathrm{CO}_{2}$ containing a small amount of water, fayalite seems to dissolve very slightly on a nanometer scale, forming a lower layer of hematite overlained by silica. It is to be noticed that the hematite and $\mathrm{Fe}^{\mathrm{III}}$-silicates synthesis, as in Table 1, require high-subcritical conditions of water, at least $300{ }^{\circ} \mathrm{C}$ and $10 \mathrm{MPa}$. The Qafoku et al. experiment if conducted at least at $300{ }^{\circ} \mathrm{C}$ and $10 \mathrm{MPa}$, would most probably show a greater amount of hematite. Magnetite is not observed since it should appear above $400{ }^{\circ} \mathrm{C}$ (see above) and siderite is observed complying the same exothermic reaction (7) of Table 1, than in the 7-days experiment when liquid water is in contact with $\mathrm{scCO}_{2}$.

Another experiment was conducted on dissolution of natural Mg-rich olivine crystals, extracted from a non-serpentinized peridotite (Olsson et al. 2012). After 4 days of reaction with oxygen deficient water at $120^{\circ} \mathrm{C}$ and 5.5-6.5 MPa, in subcritical $\mathrm{CO}_{2}$, the produced crystals were covered with a red product (Figs 8 to 10 in Olsson et al. 2012). XRD pattern "matches forsterite, hematite and magnesian calcite." X-ray photoelectron spectroscopy, XPS, shows a peak full width at half maximum, FWHM, which slightly extends towards higher binding energies suggesting "the formation of carbonates minerals, clays or silica". SEM images of the reacted olivine, show individual $1-2 \mu \mathrm{m}$ long, $\sim 100 \mathrm{~nm}$ thick, needle-like crystals associated in clusters $(\sim 800 \mathrm{~nm})$ "characteristic of goethite (Cornell \& Schwertmann 2003)" as reported by Olsson et al. (2012). Thus, at $120^{\circ} \mathrm{C}, \sim 6 \mathrm{MPa}$, far from the supercritical point of water, goethite or hematite seems present and magnetite is not. As Olsson et al. write: "What is remarkable in our experiments is that we consistently produce hematite and not the usual magnetite".

Upon comparison of the SEM images of Fig.10b in Olsson et al. (2012) and Fig.6b in Qafoku et al. (2012), I advance that the hematite particles of the Olsson Mg-rich olivine experiment morphologically approach those observed in the Qafoku experiment on natural fayalite/olivine dissolution and assigned to hematite covered with silica. Thus, both both the Mg-rich olivine (Olsson et al. 2012) and natural occuring fayalitic olivine (Qafoku et al. 2012) experiments show small amounts of hematite at lower T\&P than high-subcritical conditions of water, which is unexpected by Eq. (1) of Table 1 of the present article. But they show also no magnetite as expected. The broadening of the X-ray Photoelectron Spectroscopy, XPS, spectrum towards high-binding energies (Fig. 9 in Olsson et al. 2012) may originate in the high silica amount which is released by all hydrolysis and carbonation reactions, as shown by Bassez since 2013.

Another experiment shows that magnetite is not observed or only in trace amounts when lherzolite peridotite is altered by artificial seawater at $200{ }^{\circ} \mathrm{C} \& 50 \mathrm{MPa}, \mathrm{pH} 12.1$. The experiment was conducted by Seyfried Jr et al. (2007) and cited in Bassez (2013-2017). In extra, the presence of ferric iron is observed in two Mössbauer doublets indicating the presence of both $\mathrm{Fe}^{3+}$ and $\mathrm{Fe}^{2+}$ in the octahedral layer of the serpentine and thus confirming my above proposition of incorporation of $\mathrm{Fe}^{\mathrm{III}}$ inside the silicates which are the products of the hydrolysis of $\mathrm{Fe}^{\mathrm{II}}$-silicates by alkaline hsc water (section on Formation of $\mathrm{Fe}^{\text {III }}$-silcates).

Another experiment shows that magnetite forms only with increasing temperature: San Carlos olivine was altered at $250{ }^{\circ} \mathrm{C}-350{ }^{\circ} \mathrm{C}, 50 \mathrm{MPa}$. It is observed that: "iron was preferentially incorporated into magnetite with increasing temperature and was exclusively hosted by magnetite at $350^{\circ} \mathrm{C}$ " (Malvoisin et al. 2012). 
Finally, other experiments conducted at $300{ }^{\circ} \mathrm{C}, 35 \mathrm{MPa}$, on harzburgite containing pentlandite and pyrrhotite (Klein et al. 2015; Grozeva et al. 2017), show that magnetite appears associated with the sulfides.

Synthetic fluid inclusions in olivine allow to follow serpentinization progress at $280{ }^{\circ} \mathrm{C}$ and $50 \mathrm{MPa}$ (Lamadrid et al. 2017). The description of the experiment shows that crystals of brucite and serpentine start to appear after 15 days and magnetite after 120 days. Table 1 in Lamadrid et al. (2017) shows that magnetite is not observed in the analysis with the sample at $280{ }^{\circ} \mathrm{C}$ when the sample is removed from the furnace and quenched to room temperature for Raman analysis. That would mean that magnetite is transformed quickly with temperature and that, for conclusions on the presence of magnetite, it is important to keep the temperature of the reaction during the analysis.

As a conclusion on the analysis of these Related Laboratory Experiments, the peridotite silicates dissolve slightly in anoxic supercritical $\mathrm{CO}_{2}$. Hematite starts to form in very low amount and nanoscale sizes at low subcritical conditions of water $\left(80^{\circ} \mathrm{C} \& 90\right.$ bar). Magnetite seems to form mainly in low supercritical water. When sulfides are present in the peridotites, magnetite seems associated with the sulfides possibly following the endothermic equation of hydrolysis of sulfides instead of silicates, as proposed in Bassez (Bassez 2013-Bassez 2017a, b).

$$
\mathrm{FeS}+4 / 3 \mathrm{H}_{2} \mathrm{O} \rightarrow 1 / 3 \mathrm{Fe}_{3} \mathrm{O}_{4}+\mathrm{H}_{2} \mathrm{~S}+1 / 3 \mathrm{H}_{2} \quad 250^{\circ} \mathrm{C}, \mathrm{pH} 3.5-8
$$

\section{Conclusion of the Chapter on the Formation of Ferric Minerals in Anoxic Water}

The high solubility of $\mathrm{SiO}_{2}$ at high-subcritical, hsc, conditions of water compared to its extremely low solubility just above the critical point, triggers the dissolution of ferrous silicates with production of quartz and amorphous silica in equal amounts. The ferric oxide hydroxides goethite and lepidocrocite and their dehydrated product hematite form in the basic hsc water, together with $\mathrm{Fe}^{\mathrm{III}}$-greenalite. Silica is adsorbed on goethite and hematite, inducing more dissolution of the ferrous silicates. The solution becomes progressively supersaturated in $\mathrm{SiO}_{2}$, in a process which allows the formation of the dehydrated products minnesotaite, and most probably riebeckite and stilpnomelane. Minnesotaite, riebeckite and stilpnomelane can also incorporate the ferric iron $\mathrm{Fe}^{\mathrm{III}}$. Siderite is produced in an exothermic reaction which can proceed at various T\&P conditions (Bassez 2013-2017).

When laboratory hydrolysis occurs near the critical point of water $\left(200{ }^{\circ} \mathrm{C}, 50 \mathrm{MPa}\right)$, ferric iron is experimentally observed incorporated inside the silicate products. Thus, the new Eq. 1 of Table 1 of the present article, which describes the production of $\mathrm{Fe}^{\mathrm{III}}$ iron in anoxic and abiogenic conditions at high-subcritical conditions of water and high $\mathrm{pH}$, can explain the incorporation of $\mathrm{Fe}^{\mathrm{III}}$ inside oxides and silicates, in the absence of oxygen and microorganisms. This conclusion is applied in the next chapter to propose an alternative model for the formation of the minerals in Archean banded iron formations. As a conclusion of the present chapter, it appears that values of high $\mathrm{pH}$, and $\mathrm{T} \& \mathrm{P}$ for high-subcritical water are determinant for the production of $\mathrm{Fe}^{\mathrm{III}}$, silica in amorphous and crystalline phases, ferric oxides and ferric silicates, in anoxic and abiogenic conditions.

\section{High-Subcritical Anoxic Alkaline Water for the Formation of the Minerals Observed in Banded Iron Formations}

In this chapter, I show that the anoxic and abiogenic formation of ferric iron in high alkaline and high-subcritical water can contribute to elucidate the chemical composition of Banded Iron 
Formations, BIFs. Indeed, the minerals described in the precedent chapter as products of the hydrolyses/oxidations and carbonations of fayalite/ferrosilite, and of the consecutive dehydrations, are those observed in BIFs.

\section{Reported Mineralogies of BIFs}

For instance, BIFs are observed in the $\sim 2.5$ Ga Hamersley Group of the Pilbara craton, Western Australia and the Transvaal Supergroup of the Kaapvaal craton, South Africa. These formations are well-documented (Beukes 1984, Rasmussen et al. 2017, Haugaard et al. 2016, and refs herein) and correlation diagrams from late Neoarchean to early Paleoproterozoic stratigraphic successions, observed in the Hamersley and Transvaal basins, are drawn in Figs.5 \& 6 in Beukes and Gutzmer 2008.

In 1984, N.J. Beukes observed the iron formations of Griquatown and Kuruman both in the Asbesheuwels Subgroup of the Ghaap group, in the Griqualand west basin of the Transvaal Supergroup that overlies the Kaapvaal craton in South Africa and writes that they are "correlatives of the Penge iron formation...unmetamorphosed and structurally little deformed...oxidized to jasperoids down to depths of several tens of metres...All mineralogical information is...from diamond drill core". The minerals siderite, greenalite, minnesotaite, riebeckite are described in the Danielskuil, Skietfontein and Middelwater members of Griquatown and siderite, hematite, magnetite, stilpnomelane, chert in the Groenwater member of Kuruman. N.J. Beukes suggested "a link between the deposition of stilpnomelane and silica" and noticed that the stilpnomelane which is described by Trendall and Blockley (1970) in the Dales Gorge member of the Australian Brockman iron formation, is equivalent to the stilpnomelane observed in the South African Kuruman formation.

A very recent article reports high-resolution microscopy observations connected to energy dispersive X-ray spectroscopy, EDS, and selected area electron diffraction, SAED, of $\mu \mathrm{m}$ and $\mathrm{nm}$ iron-silicate particles in samples from the Griqualand West BIF succession (Rasmussen et al. 2017 and refs herein). Three formations are studied: Kuruman, Klein Naute and upper Nauga.

a. Chert of the $222.30 \mathrm{~m}$ deep Klein Naute formation (Fig. $6 \& 7$ in Rasmussen et al. 2017) comprises interlocking 5 to $50 \mu \mathrm{m}$ quartz grains and $50 \mathrm{~nm}$ to $1 \mu \mathrm{m}$ nanoparticles of iron silicate "comparable to greenalite nanoparticles from the Hamersley Group". In about 5\% of the cherts, densely packed greenalite form up to $50 \mu \mathrm{m}$ euhedral polygons surrounded with $\mu \mathrm{m}$-sized siderite crystals. Alternated 0.2 to $0.4 \mathrm{~mm}$ upper layers of polygons lie on microlaminated bases lined with siderite or ankerite-dolomite crystals.

b. In the $327.11 \mathrm{~m}$ upper Nauga formation (Figs. 9 and 10 in Rasmussen et al. 2017) individual particles of iron silicate are observed with sizes from $50 \mathrm{~nm}$ to $1 \mu \mathrm{m}$. The SAED patterns and the high-resolution electron microscope HREM measurements "closely match the mineral greenalite". Alternating layers of densely packed ironsilicate nanoparticles and siderite or ankerite-dolomite crystals are also observed as in the Klein Naute formation (Fig.7A) and in the $326.69 \mathrm{~m}$ upper Nauga (Fig.14).

c. The laminated chert layers with iron silicate particles in the $356.54 \mathrm{~m}$ upper Nauga formation (Fig.12 A-C) contain $0.2-0.5 \mathrm{~mm}$, fan-shaped crystals of minnesotaite "replacing chert and silicate nanoparticles". The minnesotaite has "destroyed lamination and polygonal structures". 
d. In the nodular chert layers of the $183.16 \mathrm{~m}$ Kuruman formation, banded magnetite (at least $1 \mathrm{~cm}$ thick and $3 \mathrm{~cm}$ long) (Fig. 12D) alternates with nodular chert which appears near completely replaced by a mineral identified as minnesotaite (Fig. 12 F\&G).

Therefore, greenalite appears associated with siderite $(\mathrm{a} \& \mathrm{~b})$ and minnesotaite appears replacing silica and silicate nanoparticles (most probably greenalite) in (c) and silica in (d). The minerals greenalite and siderite can be the products of primary hydrolysis and carbonation of fayalite/ferrosilite. Minnesotaite can be the product of the greenalite dehydration in water which is supersaturated with silica, thus replacing silica and greenalite. Greenalite and minnesotaite appear as primary compounds in relation to the hydrolysis and dehydration equations in alkaline hsc water that I present since 2013. The Fe-rich serpentine greenalite, and its dehydrated product minnesotaite, which are phyllosilicates, can incorporate $\mathrm{Fe}^{\mathrm{III}}$ as I propose in Bassez (2016b), Bassez (2017a, b) for the Mg-rich serpentine chrysotyle which is a T-O phyllosilicate and its dehydrated product talc which is a T-O-T phyllosilicate. This $\mathrm{Fe}^{\mathrm{III}}$ incorporation is confirmed in an article very recently published (Johnson et al. 2018) which analyzes samples of the $\sim 2.5 \mathrm{Ga}$ Australian and South-African BIFs on a nanometer scale and concludes that the observed low-Fe(III) greenalite is a primary mineral in BIFs. Finally, the magnetite which is observed in (d) can be a secondary product (Bassez 2013-2017) arising from thermal metamorphism above $400{ }^{\circ} \mathrm{C}$ or siderite decomposition $\sim 450^{\circ} \mathrm{C}, 50 \mathrm{MPa}$ or siderite hydrolysis at $300^{\circ} \mathrm{C}, 50 \mathrm{MPa}$ (above section on Formation of Iron Oxides Hydroxides in the precedent chapter).

The same chemical composition is observed in BIFs of Western Australia. The $\sim 2.45 \mathrm{Ga}$ Joffre banded BIF member of the Brockman iron formation of the Hamersley Group that overlies the Pilbara craton, has also been recently documented in detail (Haugaard et al. 2016 and refs herein). The two most dominant rock types are defined as oxide BIF and silicatecarbonate-oxide BIF. In the oxide BIF, microcrystalline chert is often found as $(0.25-1 \mathrm{~mm})$ microbands composed of hematite, carbonate, crocidolite (a derivate of riebeckite), alternating with microbands of magnetite and hematite. Some sections reveal $(<0.01 \mathrm{~mm})$ microbands of stilpnomelane. The silicate-carbonate-oxide BIF is dominated by chert, magnetite, ankerite, riebeckite, crocidolite and stilpnomelane. Braided network of hematite and minor goethite is occasionally observed. Alongside chert, dense micro- and meso- bands of magnetite are found as major constituent. After chert and magnetite, riebeckite is the most abundant. Two other type of rocks named the stilpnomelane-rich tuffaceous mudrock and the stilpnomelane mudrock contain microgranules of stilpnomelane.

Analyses of the sample ABDP9, drilled in the 2.63-2.45 Ga Hamersley Group, show that the 0.2 to $2 \mathrm{~mm}$ laminae in chert beds contain "iron silicates (stilpnomelane, riebeckite, minnesotaite, greenalite), iron oxides (hematite, magnetite), and carbonates (ankerite, siderite, calcite, dolomite)" Chert is composed of nanoparticles which are "abundant, randomly oriented, elongate...ranging from $<10 \mathrm{~nm}$ to $600 \mathrm{~nm}$ long and $\sim 1 \mathrm{~nm}$ to $50 \mathrm{~nm}$ wide... Transmission electron microscopy shows that they comprise iron-rich silicates: stilpnomelane and greenalite" (Rasmussen et al. 2015).

The 3.46 Ga old Marble Bar Chert of Pilbara craton shows also the same association of minerals with chert, hematite, magnetite, siderite and greenalite (Rasmussen et al. 2014).

Therefore, the above summary of observed minerals in the $\sim 2.5 \mathrm{Ga}$ Transvaal and Hamersley BIFs and in the 3.46 Ga Marble Bar Chert are those of the anoxic hydrolyses and carbonations of fayalite/ferrosilite-rich silicate rocks together with the dehydrated products as described in Table 1 and Fig.1. Both Kaapvaal and Pilbara cratons show minerals in their 
BIFs which can be classified as oxides, silica, silicates and carbonates. The oxides, and silicates to a less extent, are observed to contain ferric iron. Minnesotaite, as expected for a direct dehydrated product of greenalite, appears directly associated with greenalite and chert in Transvaal. Minnesotaite is not reported, neither greenalite, in the Joffre formation (Fig.2 in Haugaard et al. 2016), where instead, the dehydrated silicates are observed, talc, riebeckite, crocidolite, stilpnomelane. The Joffre formation may be a case of high silica content of the interacting hsc water, leading to little greenalite and minnesotaite which dehydrated into stilpnomelane, riebeckite and crocidolite. Stilpnomelane is not reported by B. Rasmussen et al. (2017) in Kuruman, Klein Naute neither upper Nauga. However, it was observed by N.J. Beukes (1984) in the Groenwater member of the Kuruman formation. Stilpnomelane is observed with greenalite in the sample BDP9 of Hamersley, suggesting that stilpnomelane formed at the same time than greenalite. The nanosizes of the observed particles can originate in high-subcritical water as described in the next section.

\section{A Proposed Scenario for the Formation of Minerals in BIFs}

Thus, it is possible to propose that the BIF minerals of the Transvaal Supergroup and Hamersley Group, both dated late Neoarchean-early Paleoproterozoic periods, and the BIF minerals of the Archean Marble Bar Chert, formed under the same process of fayalite/ ferrosilite hydrolyses and carbonation. This process, is governed first by anoxic alkaline water just below its critical point, which triggers the anoxic oxidation of $\mathrm{Fe}^{\mathrm{II}}$ and consequently the formation of hematite and $\mathrm{Fe}^{\mathrm{III}}$-silicates, with secondary magnetite, and second by the high dissolution of silica in high-subcritical water which leads to the dehydration products minnesotaite, riebeckite, stilpnomelane. Alkaline $\mathrm{pH}$ is determinant and also the T\&P values of hsc water. A confirmation of the influence of hsc water is noticed in the sizes of the finegrained and nanoparticles which are observed both in BIFs and in supercritical water laboratory experiments. These T\&P subcritical conditions, that crustal silicate rocks may encounter, are probably caused by a periodic convective movement inside the mantle which is associated to a still unknown magma variation.

Therefore, the chemical Eq. (1) of Table 1, that represents the alkaline anoxic oxidation of ferrous iron into ferric iron, can be applied to explain the source of ferric iron in minerals deposits and a possible scenario may be as follows:

Fayalite is an abundant mineral which composes the rocks of the Earth's crust and upper mantle, together with ferrosilite. During late archean times, due to hot magma (Condie et al. 2016; Condie 2016) and tectonic movement (Klein et al. 2017) numerous subduction zones create fractures leading to hydrothermal eruptions. At depth, water is much above its critical point. Above $100 \mathrm{MPa}$ and $450{ }^{\circ} \mathrm{C}, \mathrm{SiO}_{2}$ highly dissolves. Rising water decreases in temperature and pressure, and silica precipitates when at the specific T\&P just above the critical point of water, as described in the section on Dissolution of Silica of the precedent chapter. Then, at high-subcritical conditions, part or all of the precipitated silica can redissolve. If at that point, crustal rocks containing fayalite/ferrosilite are in contact with alkaline hsc water which is undersaturated in silica, fayalite/ferrosilite can dissolve. Ferrous iron is oxidized into ferric iron with release of $\mathrm{H}_{2}$. The ferric oxide hydroxide goethite and the oxide hematite, form. Magnetite forms as a secondary product. It is indeed observed as crosscutting primary laminations of chert as for instance in the Moodies Group (Bontognali et al. 2013).

Silica dissolves until saturation. Upon Fig.3\&4 of the Karasek et al. 2013a article, discussed in the precedent chapter, dissolved silica at high-subcritical T\&P is in equal amounts of 
crystalline and amorphous phases. Thus, when thermal quenching occurs in cooled oceans or shallow waters, silica can keep its high $\mathrm{T}$ proportions and be of two types, crystalline quartz and amorphous silica glass. The quenched silica can be nanosized $\alpha$-quartz containing some amorphous structures as demonstrated in the Bertone et al. laboratory experiment (Bertone et al. 2003). Depending on the $\mathrm{pH}$ of the hsc water, the amount of the amorphous phase varies. Since it is usually considered that the quenching process shows minerals which are produced at high T, without structural rearrangement, I propose that $\alpha$-quartz forms in hsc together with $\alpha$ quartz incorporating disordered domains and $\mathrm{Fe}^{\mathrm{III}}$, leading to the $\mathrm{Fe}^{\mathrm{III}}$-greenalite mineral. It is to be noticed that some chert of BIFs is composed of hard, very fine-grained silica. In supercritical hydrothermal synthesis conducted in the laboratory, submicron-sized particles instead of micron-sized, form, as shown in the synthesis of talc conducted in supercritical water at $500{ }^{\circ} \mathrm{C}$ and $40 \mathrm{MPa}$, followed by thermal quenching in ice (Dumas et al. 2016). Also, the Alonso-Dominguez et al. (Alonso-Domínguez et al. 2017) experiment, cited above, shows mean particle sizes around $30 \mathrm{~nm}$ for all the iron oxides hematite, magnetite, maghemite, and oxide hydroxides $\mathrm{FeO}(\mathrm{OH})$, which are synthesized in supercritical water. It is thus possible to propose that the silica which dissolves from fayalite/ferrosilite at conditions near supercritical, forms under sub-micrometer sizes and that the process of quenching allows these sizes to be preserved. The nanosize synthesis of minerals in near supercritical water can thus be at the origin of the sizes and textures of minerals in BIFs. They can form through fayalite/ferrosilite hydrolysis following a triggering effect produced by the alkaline interacting water in the nearsupercritical state.

When water reaches saturation in $\mathrm{SiO}_{2}$, the dehydrated products minnesotaite forms and most probably stilpnomelane and riebeckite. However, when the rising water is silica-rich, greenalite can readily dehydrate into minnesotaite, stilpnomelane and riebeckite, leading to smaller quantities of greenalite as observed in the $\sim 2.45$ Ga Joffre banded BIF member of the Brockman iron formation, Hamersley Group (Haugaard et al. 2016, \& above section). When $\mathrm{CO}_{2}$ is present, siderite can be produced in a hsc water which is undersaturated in silica. Considering Eqs. (2-10) it sems that neither siderite, nor silicates, nor oxide hydroxides, nor hematite can form in a rising hsc water which is already supersaturated in silica, since dissolution of fayalite or ferrosilite producing silica cannot occur.

\section{Conclusion on the Formation of Minerals in BIFs}

Therefore, the formation of the BIF minerals may depend on four characteristics of water which act together in a specific point of space and time at a right kairos: water in its high-subcritical state $\left(300{ }^{\circ} \mathrm{C}-350{ }^{\circ} \mathrm{C}, 10 \mathrm{MPa}-22 \mathrm{MPa}\right)$, high $\mathrm{pH}(9.5-14)$, undersaturated in silica, and interacting with crustal rocks containing fayalite/ferrosilite. This conjunction of events in time and space may happen only rarely and depends on the temperature, pressure and composition of the rising water. Consequently, I propose that it is the state of water which is just below the supercritical state which triggers the formation of very fine-grained oxides and silicates. If water encounters fayalite/ ferrosilite while in high supercritical state, containing thus high levels of dissolved $\mathrm{SiO}_{2}$ at saturation, no fayalite/ferrosilite dissolves. If the encounter occurs at very low subcritical conditions, where the solubility of silica is very low, no silica can dissolve and consequently no fayalite/ferrosilite dissolves. In both cases, $\mathrm{Fe}^{\mathrm{II}}$ is not oxidized into $\mathrm{Fe}^{\mathrm{III}}$. Hydrolysis of fayalite/ferrosilite does not start and minerals are no not ejected from a possible venting arc. After many years, hydrolysis of fayalite/ferrosilite starts 
again when temperature and pressure of the alkaline silica-undersaturated water reach highsubcritical values. The synthesized minerals are again ejected from plumes, creating layers depending on gravity: hematite has a specific gravity of $\sim 5.26$, magnetite $\sim 5.18$, siderite $\sim 3.96$, riebeckite $\sim 3.30$, ankerite $\sim 3.10$, minnesotaite $\sim 3.01$, dolomite 2.86 , stilpnomelane $\sim 2.59$ 2.96, quartz 2.59-2.65 (Anthony et al., 2004-2017). Thus, silica should overlain hematite creating adsorbed bonds as experimentally observed (section on Dissolution of Fayalite and Formation of Dissolved $\mathrm{Fe}^{2+}$ in the first chapter of Results). Cohesion between all molecules proceed during years. I suggest that this periodic change in temperature may result from a periodic convective process inside the mantle arising from magma variation. However, knowledge of such process is not yet enough documented.

\section{High-Subcritical Anoxic Alkaline Water for the Process of Geobiotropy inside Fluid Inclusions}

In this chapter, I show that fluid inclusions inside rocks, may contain macromolecules of amino acids, which can be synthesized in anoxic conditions at $300{ }^{\circ} \mathrm{C}-350{ }^{\circ} \mathrm{C}$ or by microwave or gamma ray excitation.

\section{CO Is Needed for Prebiotic Synthesis}

The equation of anoxic oxidation of ferrous iron (Eq.1) releases $\mathrm{H}_{2}$ at $\sim 300^{\circ} \mathrm{C}-350{ }^{\circ} \mathrm{C}$ and $\sim 10 \mathrm{MPa}-25 \mathrm{MPa}$ and not above the critical point of water. This $\mathrm{H}_{2}$ can form bubbles and be associated with other dissolved gases and liquids inside fluid inclusions containing for instance $\mathrm{H}_{2}, \mathrm{H}_{2} \mathrm{O}, \mathrm{CO}_{2}, \mathrm{~N}_{2}, \mathrm{CH}_{4}$. At these specified temperatures and pressures, hydrogenation of carbon dioxide can proceed to form CO. It is worth here remembering the 1902 Sabatier \& Senderens reactions which showed direct formation of methane from mixtures of gaseous $\mathrm{H}_{2}$ and $\mathrm{CO}_{2}$ at $350{ }^{\circ} \mathrm{C}$ with $\mathrm{Ni}$, and $300{ }^{\circ} \mathrm{C}$ (with higher rates at $360{ }^{\circ} \mathrm{C}$ and $400{ }^{\circ} \mathrm{C}$ ) with $\mathrm{Co}$. Methane did not form with $\mathrm{Cu}$ at $430{ }^{\circ} \mathrm{C}$, instead $\mathrm{CO}$ formed, and neither $\mathrm{CH}_{4}$ nor $\mathrm{CO}$ formed below $420{ }^{\circ} \mathrm{C}$ with $\mathrm{Fe}$ (Sabatier and Senderens 1902). A more recent experiment conducted with $\mathrm{H}_{2(\mathrm{~g})}$ at $500{ }^{\circ} \mathrm{C}$ on $\mathrm{CO}_{2(\mathrm{~g})}$ with the catalyst $\mathrm{Cu} / \mathrm{Al}_{2} \mathrm{O}_{3}$, produced $\mathrm{CO}$ and not $\mathrm{CH}_{4}$ (Chen et al. 2000), thus confirming the Sabatier reaction. Fischer-Tropsch reactions (1923) were involved in the transformation of gaseous $\mathrm{CO}_{2} \mathrm{H}_{2}$ into liquid hydrocarbons at $450{ }^{\circ} \mathrm{C}-50$ bar in the presence of Fe. More recent experiments conducted on mixtures of dissolved $\mathrm{H}_{2}$ and $\mathrm{CO}_{2}$ in sea water at $250{ }^{\circ} \mathrm{C}-300{ }^{\circ} \mathrm{C}, 25 \mathrm{MPa}$ and $\mathrm{Fe}_{3} \mathrm{O}_{4}$ as catalyst, showed formation of dissolved $\mathrm{CO}$ with minor dissolved $\mathrm{CH}_{4}$ (Fu and Seyfried Jr 2009). The $\mathrm{Fu} \&$ Seyfried conditions are those of hsc water.

$$
\mathrm{CO}_{2(\text { dis })}+\mathrm{H}_{2(\text { dis })} \rightarrow \mathrm{CO}_{(\text {dis })}+\mathrm{CH}_{4(\text { dis })} \quad 250^{\circ} \mathrm{C}-300^{\circ} \mathrm{C}, 25 \mathrm{MPa}, \mathrm{Fe}_{3} \mathrm{O}_{4}
$$

(Fu and Seyfried Jr 2009)

When $\mathrm{CO}_{2}, \mathrm{H}_{2}, \mathrm{CO}$ and $\mathrm{CH}_{4}$ are dissolved in the aqueous liquid solution of a fluid inclusion, they coexist with their vapor phases. Therefore, following the formation of $\mathrm{CO}$, either in gaz or dissolved phases, prebiotic chemistry based on $\mathrm{CO}$ and $\mathrm{N}_{2}$ in the gas phase, can proceed either with heat through Sabatier-Senderens/Fischer-Tropsch reactions $\left(\mathrm{CO}+\mathrm{H}_{2}\right)$ associated to Haber-Bosch $\left(\mathrm{H}_{2}+\mathrm{N}_{2}\right)$ reactions, or with active nitrogen $\left(\mathrm{N}_{2}{ }^{*}\right)$ produced in microwave excitation, or with gamma-ray excitation as described below. 


\section{Published Laboratory Experiments of Prebiotic Synthesis (Table 2)}

In 1996, Nils Holm proposed that Fischer-Tropsch Type synthesis of organic compounds could occur following the serpentinization of peridotite in the oceanic crust. In 2003 Hill \& Nuth conducted a Sabatier-Senderens/Fischer-Tropsch \& Haber-Bosch experiment with a gas mixture of 75 Torr $\mathrm{CO}, 75$ Torr $\mathrm{N}_{2}$ and 550-650 Torr $\mathrm{H}_{2}(\sim 1$ atm pressure) and temperatures between $200{ }^{\circ} \mathrm{C}$ and $600{ }^{\circ} \mathrm{C}$. The catalysts are iron silicates smokes containing mainly iron silicates and silica and minor iron oxides $\mathrm{Fe}_{2} \mathrm{O}_{3}$ and $\mathrm{Fe}_{3} \mathrm{O}_{4}$. "The individual grains are nanodimensioned ( 20-50 $\mathrm{nm})$ and have enormous defect-rich surface areas that provide numerous sites for catalysis." Figures concerning experiments at $300{ }^{\circ} \mathrm{C}$ and $400{ }^{\circ} \mathrm{C}$ during $\sim 70 \mathrm{~h}$, report the presence of nitrogen-containing organic molecules, " $\mathrm{C}-\mathrm{N}$ species" assigned to methyl amine $\mathrm{CH}_{3} \mathrm{NH}_{2}$, acetonitrile $\mathrm{CH}_{3} \mathrm{CN}$ and $\mathrm{N}$-methyl methylene imine $\mathrm{CH}_{3} \mathrm{~N}=\mathrm{CH}_{2}$.

The 2012 Pizzarello experiment was conducted with $\mathrm{CO}, \mathrm{H}_{2}$, and $\mathrm{NH}_{3}$ gases in 1:1:1 ratio at $370{ }^{\circ} \mathrm{C}$ for $24 \mathrm{~h}$, and with meteoritic minerals as catalysts. "The tubes were evacuated" and pressure of the reaction was a few $\mathrm{mm} \mathrm{Hg}$ (Pizzarello, personal communication 2017). Amino acids (in nmol/g) were detected: glycine (436) and alanine (407) were obtained with the iron meteorite Santiago Papasquiaro $(7.48 \% \mathrm{Ni})$. The magnetite powder led to 2-amino isobutyric acid (540.0), glycine (121.9), alanine (88.0), 2-amino butyric acid (20.3), norvaline (4.5), norleucine (2.2), isovaline (1.0).

The following paragraph introduces the characteristics of the detected amino-acids together with their nomenclature. Glycine $\mathrm{NH}_{2} \mathrm{CH}_{2} \mathrm{COOH}$ and alanine $\mathrm{CH}_{3} \mathrm{CH}\left(\mathrm{NH}_{2}\right) \mathrm{COOH}$ are protein $\alpha$-amino carboxylic acids (with group - $\mathrm{COOH}$ ) coded by human DNA. The Aib, 2-amino isobutyric acid, $\mathrm{C}_{3} \mathrm{H}_{3} \mathrm{C}^{2}\left(\mathrm{CH}_{3}\right)\left(\mathrm{NH}_{2}\right) \mathrm{C}^{1} \mathrm{OOH}$ is also named 2-amino 2methylpropionic acid and 2-methylalanine. Iva, Isovaline, $\mathrm{C}^{4} \mathrm{H}_{3} \mathrm{C}^{3} \mathrm{H}_{2} \mathrm{C}^{2}\left(\mathrm{CH}_{3}\right)\left(\mathrm{NH}_{2}\right) \mathrm{C}^{1} \mathrm{OOH}$, an isomer of the human DNA-coded valine, is also named 2-amino 2-methylbutanoic acid and 2-ethylalanine. The two $\alpha$-amino acids, Aib and Iva, are not coded by human DNA, but are synthesized by fungi. A GC/SIMS-MS on Chirasil-L Val, culture-analysis of 49 species of fungi, show that Aib is of higher abundance and Iva forms in $(R)$ (=D) configuration or as a mixture of $(S)(=\mathrm{L})$ and $(R)(=\mathrm{D})$ enantiomers (Brückner et al. 2009). The non-human-DNA-coded 2-amino butyric acid, $\mathrm{C}^{4} \mathrm{H}_{3} \mathrm{C}^{3} \mathrm{H}_{2} \mathrm{C}^{2} \mathrm{H}\left(\mathrm{NH}_{2}\right) \mathrm{C}^{1} \mathrm{OOH}$, also named 2-amino butanoic acid and $\alpha$-amino butanoic acid, $\alpha$-ABA, is found in the exudate of germinating canola seeds (Moe 2013). Norvaline $\mathrm{CH}_{3} \mathrm{CH}_{2} \mathrm{CH}_{2} \mathrm{CH}\left(\mathrm{NH}_{2}\right) \mathrm{COOH}$, named also 2-amino pentanoic acid and norleucine $\mathrm{CH}_{3}\left(\mathrm{CH}_{2}\right)_{3} \mathrm{CH}\left(\mathrm{NH}_{2}\right) \mathrm{COOH}$, named also 2-amino hexanoic acid are synthesized by the bacterium Escherichia coli (Biermann et al. 2013). The non-human-DNA coded isovaline and norvaline are observed in racemic amounts in the Murchison meteorite together with the extraterrestrial 2-amino-2,3dimethylpentanoic acid, 2-a-2,3-dmpa, $\mathrm{CH}_{3} \mathrm{CH}_{2} \mathrm{CH}\left(\mathrm{CH}_{3}\right) \mathrm{C}\left(\mathrm{CH}_{3}\right)\left(\mathrm{NH}_{2}\right) \mathrm{COOH}$, which is detected with L-enantiomer excess, $\mathrm{L}_{\mathrm{ee}}$ (Cronin and Pizzarello 1997). Another analysis on different samples of the Murchison meteorite shows a large $\mathrm{L}_{\mathrm{ee}}$ of isovaline, norvaline and valine (Glavin and Dworkin 2009). Some of these amino acids are described in (Bassez 1998-2018).

Active nitrogen can also excite $\mathrm{CH}_{4}$ or mixtures of $\mathrm{CO}+\mathrm{H}_{2}$, in the gas and liquid phases. Active nitrogen is composed of nitrogen atoms in the ground state $\mathrm{N}\left({ }^{4} \mathrm{~S}\right)$ and nitrogen molecules in the ground singlet state $\mathrm{N}_{2}\left(\mathrm{X}^{1} \Sigma_{\mathrm{g}}{ }^{+}\right)$and in the excited triplet state $\mathrm{N}_{2}\left(\mathrm{~A}^{3} \Sigma_{\mathrm{u}}{ }^{+}\right)$. The transition $\mathrm{A}^{3} \Sigma_{\mathrm{u}}{ }^{+}-\mathrm{X}^{1} \Sigma_{\mathrm{g}}{ }^{+}$being forbidden, active nitrogen shows a high reactivity (Bassez 1971). Active nitrogen formed with microwave radiation, at $\sim 2.45 \mathrm{GHz}$ from a magnetron, in a reaction chamber at a few $\mathrm{mmHg}$ and was used to study the diatomic radicals NS, NSe and 
NTe (Bassez 1971). The formation of cyanides was reported by M. Berthelot (1868) when "free nitrogen" reacted with acetylene $\mathrm{C}_{2} \mathrm{H}_{2}$ in spark discharges. Blades and Winkler (1951) found that nitrogen atoms react on methane $\mathrm{CH}_{4}$ and ethane $\mathrm{C}_{2} \mathrm{H}_{6}$ leading to hydrogen cyanide $\mathrm{HCN}$ at temperatures between $350^{\circ} \mathrm{C}-450{ }^{\circ} \mathrm{C}$, and not at $200{ }^{\circ} \mathrm{C}$. Moser et al. (1968) reported a peptide synthesis through $\mathrm{HCN}$ polymerization in alkaline medium as described in (Rauchfuss 2008 p.104). Cyanides being very reactive it is most probable that molecules of biological interest form when $\mathrm{CH}_{4}$ or light hydrocarbons or mixtures of $\mathrm{CO}_{2}$ and $\mathrm{H}_{2} / \mathrm{H}_{2} \mathrm{O}$ in anoxic alkaline high-subcritical water are excited with active nitrogen.

Another kind of synthesis of amino acids occurs when mixtures of simple molecules including $\mathrm{CO}$ are excited by particles of cosmic radiation, as demonstrated in the Kobayashi experiments (Kobayashi et al. 1990-Kobayashi et al. 2008). Macromolecules composed of amino-acids form when mixtures of gaseous $\mathrm{CO}, \mathrm{N}_{2}$, above liquid $\mathrm{H}_{2} \mathrm{O}$ or $\mathrm{CO}, \mathrm{NH}_{3}, \mathrm{H}_{2} \mathrm{O}$, or some of the various elementary molecules $\mathrm{CH}_{4}, \mathrm{CO}_{2}, \mathrm{CO}, \mathrm{N}_{2}, \mathrm{NH}_{3}, \mathrm{H}_{2} \mathrm{O}$, are excited with particles of matter and interaction of the cosmic radiation such as, protons, He ions, e $\mathrm{e}^{-}$soft Xrays, $\gamma$-rays. The $G$-value of glycine, which is the number of molecules formed per $100 \mathrm{eV}$ absorbed, is 0.02 for gamma rays of low-dose rate $\left(<5 \mathrm{~Gy} / \mathrm{h}\right.$ or $\left.5 \mathrm{~J}^{\mathrm{kg}} \mathrm{kg}^{-1} \cdot \mathrm{h}^{-1}\right)$. This $G$-value is the

Table 2 Amino-acids precursors (Hill\&Nuth) and amino-acids formed during the combined Sabatier-Senderens/ Fischer-Tropsch \& Haber-Bosch reactions (left column) and during $\gamma$-ray/proton excitation (right column)

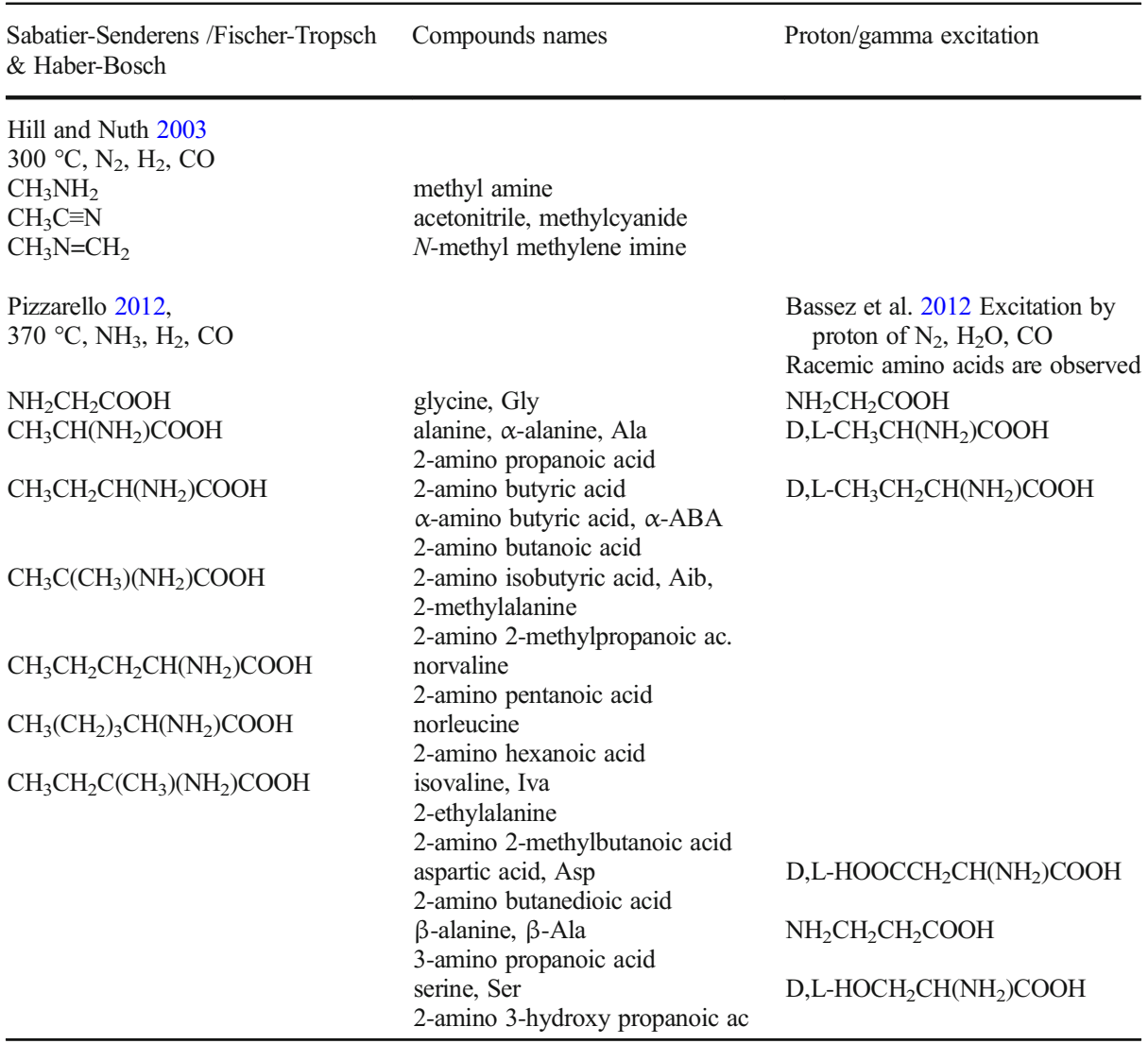


same with $3 \mathrm{MeV}$ proton beams. The $G$-value is much lower, 0.001 , for gamma rays of highdose rate $(>90 \mathrm{~Gy} / \mathrm{h})$ (Kobayashi et al. 2008). The yellow-brown products obtained with $3 \mathrm{MeV}$ proton irradiation of $\left(\mathrm{CO}, \mathrm{N}_{2}, \mathrm{H}_{2} \mathrm{O}\right)$ when analyzed by Gas Chromatography-Mass Spectrum, GC-MS, shows in decreasing amounts, glycine and racemic mixtures of D and L enantiomers: D,L-alanine, (D,L-Ala); D,L- $\alpha$-amino butyric acid (D,L- $\alpha$-ABA); D,L-aspartic acid (D,L-Asp); $\beta$-alanine ( $\beta$-Ala); D,L-serine (D,L-Ser) and others in minor amounts (Bassez et al. 2012). $\beta$-alanine $\mathrm{NH}_{2} \mathrm{CH}_{2} \mathrm{CH}_{2} \mathrm{COOH}$ is achiral. Lower resolution chromatograms conducted earlier showed approximately the same amino acids: glycine, D,L-alanine, $\beta$ alanine, D,L-aspartic acid, L-serine $\mathrm{HOCH}_{2} \mathrm{CH}\left(\mathrm{NH}_{2}\right) \mathrm{COOH}$ (Kobayashi et al. 1998). All of the above described amino acids, products of Sabatier-Senderens/Fischer-Tropsch \& HaberBosch and gamma-excitation reactions are summarized in Table 2.

These abiotic syntheses of amino-acids require $\mathrm{CO}$ to form and not $\mathrm{CO}_{2}$. This fact was observed by Schlesinger and Miller (1983) and Kobayashi et al. (1990). I propose that CO can form inside fluid inclusions when $\mathrm{CO}_{2}$ and $\mathrm{H}_{2}$ are present at $\sim 300{ }^{\circ} \mathrm{C}-350{ }^{\circ} \mathrm{C}$ and $10 \sim 25 \mathrm{MPa}$. These T\&P values are those of high-subcritical water which allow silica to dissolve and induce the hydrolysis of iron-olivine and -pyroxenes as shown in the precedent chapter. I proposed earlier (Bassez 2008) to mix peridotite, sea-water and $\mathrm{N}_{2}$ in reactors and then increase temperature and pressure to high-subcritical and low supercritical conditions of water. With $\mathrm{CO}_{2}$ included inside the rock, $\mathrm{CO}$ may form with $\mathrm{H}_{2}$ that is released during serpentinization of the peridotite, or $\mathrm{CO}_{2}$ can also be added to the reactor: "De la péridotite, au contact de l'eau de mer sous HT-HP conduirait à la formation de $\mathrm{H}_{2}$ et $\mathrm{CH}_{4}$ ainsi qu'à de la magnétite. En ajoutant de l'azote liquide et/ou de la carboglace...dans un réacteur qui serait ensuite ajusté en pression et température...L'expérience pourrait également partir d'olivine et de pyroxènes....une analyse Raman permettrait l'analyse in-situ des molécules synthétisées...Les réactifs $\mathrm{H}_{2} \mathrm{O}, \mathrm{H}_{2}, \mathrm{CH}_{4}$, et $\mathrm{N}_{2}$ qui donnent la plus grande abondance en composés organiques d'intérêt biologique dans les expériences de Miller, seraient réunis." In english words: "Peridotite, in contact with sea water under high $\mathrm{T}$ high $\mathrm{P}$ would lead to the formation of $\mathrm{H}_{2}$ and $\mathrm{CH}_{4}$ and magnetite. By addition of $\mathrm{N}_{2}$ and/or $\mathrm{CO}_{2}$...in a reactor which would be adjusted in pressure and temperature...The experiment could also be conducted with olivine and pyroxenes...In situ analysis of the synthesized molecules could be conducted with Raman spectroscopy...The reactants $\mathrm{H}_{2} \mathrm{O}$, $\mathrm{H}_{2}, \mathrm{CH}_{4}$, and $\mathrm{N}_{2}$ which are known to produce the highest abundance of organic compounds of biological interest in the Miller experiments, would be assembled", and prebiotic synthesis in hydrothermal conditions can be achieved. Considering the mineral part, this theoretical proposition is currently demonstrated in a very recent experiment (Lamadrid et al. 2017) which shows water of a synthetic fluid inclusion at $280{ }^{\circ} \mathrm{C}, 50 \mathrm{MPa}$, interacting with the olivine hosting the inclusion. The olivine seems Mg-rich. Raman spectra show serpentine, brucite, water and hydrogen. The next step of this experiment could be the introduction of $\mathrm{CO}_{2}$ and $\mathrm{N}_{2}$ or $\mathrm{NH}_{3}$ at $350^{\circ} \mathrm{C}$ and $25 \mathrm{MPa}$ inside the synthetic fluid inclusion. $\mathrm{CO}_{2}$ reacting with $\mathrm{H}_{2}$ would lead to $\mathrm{CO}$ and the mixture of $\mathrm{CO}, \mathrm{N}_{2} / \mathrm{NH}_{3}, \mathrm{H}_{2}$ could lead to the synthesis of prebiotic molecules such as macromolecules of amino acids as described above.

\section{Geological Field Observations and Discussion}

Fluid inclusions are observed in many rocks (Hurai et al. 2015; Pironon et al. 2017). In 1996, D. Kelley writes: "Analyses of fluid inclusions in plutonic rocks recovered from the slowspreading Southwest Indian Ridge (SWIR) record $\mathrm{CH}_{4}$ concentrations of 15-40 times those of hydrothermal vent fluids and of basalt-hosted volcanic gases and provide the first direct 
sampling of $\mathrm{CO}_{2}-\mathrm{CH}_{4}-\mathrm{H}_{2} \mathrm{O}-\mathrm{H}_{2}-\mathrm{C}$ bearing fluids in the oceanic crust...The inclusions may record respeciation of magmatic fluids attendant with the inward diffusion of $\mathrm{H}_{2}$ into the inclusions...".

In 2015, McDermott et al. observed a great abundance of dissolved $\mathrm{H}_{2}$ and $\mathrm{CH}_{4}$ in the $\sim 2350 \mathrm{~m}$ deep Von Damm Venting Field, VDVF. They propose that " $\mathrm{CH}_{4}$ and the higher hydrocarbons are likely formed in $\mathrm{H}_{2}$-rich fluid inclusions over geological timescales...Our results indicate that $\mathrm{CH}_{4} \ldots$ and higher n-alkanes may form independently of actively circulating serpentinizing fluids in ultramafic-influenced systems".

As a complement, I like to remember here the observation I report since 2013 and that is presented in detail in Bassez (2017a, b). The Pourbaix diagram drawn by Digby D. Macdonald in (Macdonald 1992) for the system $\mathrm{Fe}-\mathrm{S}-\mathrm{H}_{2} \mathrm{O}$ shows that ferrous monosulfides are transformed at $25{ }^{\circ} \mathrm{C}$ and $\mathrm{pH} \sim 5.4$ to 9.5 , into ferrous disulfides such as pyrite, upon the wellknown following equation:

$$
\mathrm{Fe}^{\mathrm{II}} \mathrm{S}_{(\mathrm{s})}+\mathrm{H}_{2} \mathrm{~S}_{(\mathrm{dis})} \rightarrow \mathrm{Fe}^{\mathrm{II}} \mathrm{S}_{2(\mathrm{~s})}+\mathrm{H}_{2(\mathrm{~g})} \quad 25^{\circ} \mathrm{C}, \mathrm{pH} 5.4-9.5
$$

However, the diagram drawn at $250{ }^{\circ} \mathrm{C}$ shows at $\mathrm{pH} \sim 3.5-8$ that $\mathrm{Fe}^{\mathrm{II}}$-monosulfides are hydrolyzed into magnetite upon the chemical equation that I rewrite below:

$$
\mathrm{Fe}^{\mathrm{II}} \mathrm{S}_{(\mathrm{s})}+4 / 3 \mathrm{H}_{2} \mathrm{O}_{(\mathrm{l})} \rightarrow 1 / 3 \mathrm{Fe}^{\mathrm{II}} \mathrm{Fe}^{\mathrm{III}}{ }_{2} \mathrm{O}_{4(\mathrm{~s})}+\mathrm{H}_{2} \mathrm{~S}_{(\text {dis })}+1 / 3 \mathrm{H}_{2(\mathrm{~g})} \quad 250^{\circ} \mathrm{C}, \mathrm{pH} 3.5-8
$$

This hydrolysis of ferrous monosulfides can explain the formation of magnetite, $\mathrm{H}_{2} \mathrm{~S}$ and $\mathrm{H}_{2}$ at $\mathrm{pH} \& \mathrm{~T}$ which correspond to the VDVF.

Indeed, the highest temperature Von Damm fluids of the East Summit vent are blown at $226{ }^{\circ} \mathrm{C}, \mathrm{pH} \sim 5.6,\left[\mathrm{H}_{2}\right] \sim 17 \mu \mathrm{mol} / \mathrm{L},\left[\mathrm{CH}_{4}\right] \sim 2.67 \mathrm{mmol} / \mathrm{L}$ (McDermott et al. 2015), $\left[\mathrm{CO}_{2}\right] \sim 2.8 \mathrm{mmol} / \mathrm{L},\left[\mathrm{H}_{2} \mathrm{~S}\right] \sim 3 \mathrm{mmol} / \mathrm{L}$ and $\mathrm{nmol} / \mathrm{L}$ of dissolved $\mathrm{C}_{2} \mathrm{H}_{6}, \mathrm{C}_{3} \mathrm{H}_{8}, \mathrm{n}-\mathrm{C}_{4} \mathrm{H}_{10}$, i$\mathrm{C}_{4} \mathrm{H}_{10}$ (Table 1, p92 in McDermott 2015). The VDVF field is located on a peridotite-gabbro basement. Gabbroic rocks are known to contain sulfur compounds and therefore $\mathrm{H}_{2}$ may originate from the anoxic hydrolysis of ferrous monosulfides as written above. The host rocks of the VDVF, as described in Hodgkinson et al. (2015) \& Hodgkinson (2015), contain a serpentinized peridotite with magnetite, Cr-spinel and pyrrhotite (p123 in Hodgkinson 2015). Many associations of talc, with the disulfides chalcopyrite $\mathrm{CuFeS}_{2}$, pyrite $\mathrm{FeS}_{2}$, and the monosulfides sphalerite $(\mathrm{Zn}, \mathrm{Fe}) \mathrm{S}$, galena $\mathrm{PbS}$, bornite $\mathrm{Cu}_{5} \mathrm{FeS}_{4}$ are described. "Sulphides in active chimneys consist of chalcopyrite, pyrite, sphalerite and galena...Sphalerite...occurs... with chalcopyrite or...disseminated in talc along with euhedral cubes of pyrite. Clusters of sulphides at chimneys from the main cone always contain chalcopyrite or pyrite, along with sphalerite or galena, i.e. galena and sphalerite grains are not observed by themselves." (p140 in Hodgkinson 2015). Thus, it seems that a relation between iron monosulfides and disulfides, as the one written above, can lead to the high concentration of $\mathrm{H}_{2} \mathrm{~S}$ observed in the VDVF and to the attendant $\mathrm{H}_{2}$. Therefore, as I write in Bassez (2017a, b): "Consequently, as I proposed earlier (Bassez, 2013; Bassez 2016a, b), it may be suggested that it is the hydrolysis/oxidation of ferrous sulfide in the absence of oxygen... and not the hydrolysis/oxidation of ferromagnesian silicate, which contributes to explain the low values 3-4 and the $\mathrm{H}_{2} \mathrm{~S}$ concentration between 1.2 and $11 \mathrm{mmol} / \mathrm{kg}$, observed at all high T, low pH fields."

FeS hydrolysis is highly endothermic but can proceed within the heat of hydrothermal water complemented by the heat produced by the hydrolysis of Mg-olivine which is exothermic (Bassez 2017a, 2017b). Mg-olivine leads to the serpentine chrysotile which leads to talc. Talc can form in a solution supersaturated in silica by the way of a reaction which is calculated slightly exothermic at 
$25^{\circ} \mathrm{C}$. Since silica can dissolve at $226^{\circ} \mathrm{C} \& 23 \mathrm{MPa}$ which is the hydrostatic pressure at the location of the $2350 \mathrm{~m}$ deep VDVF, water at the VDVF can be supersaturated in silica and talc forms easily in these T\&P values which are those of high-subcritical water as discussed above. Therefore, it is plausible that the VDVF sulfides contribute to the great amount of $\mathrm{H}_{2} \& \mathrm{H}_{2} \mathrm{~S}$, and to the decrease of $\mathrm{pH}$ compare to Lost City where most probably only ferromagnesian silicate hydrolysis occurs. This hypothesis of sulfide hydrolysis within the heat of Mg-olivine hydrolysis confirms the observation of mono- and di-sulfides disseminated inside talc. However, if the process of monosulfide hydrolysis at $\sim 226^{\circ} \mathrm{C}$ is plausible for the VDVF, magnetite deposits should be observed inside the mound below the VDVF as I discussed for the TAG and Rainbow fields in Bassez (2017a, b). A search for magnetic anomalies could be conducted at the VDVF.

A recent experiment reports analyses of micrometer-sized inclusions of the $3.7 \mathrm{Ga}$ old Isua Supracrustal belt, West Greenland (Hassenkam et al. 2017). The high-resolution observations with atomic force microscopy coupled to infrared spectroscopy, AFM-IR, show absorption spectra with a spatial resolution of $10 \mathrm{~nm}$ and the analysis concludes in the presence of functional organic groups composed of the elements $\mathrm{C}, \mathrm{H}, \mathrm{O}, \mathrm{N}$ and perhaps $\mathrm{P}$.

Oil of different origins seem to appear in fluid inclusions. Oil-bearing fluid inclusions are observed in the $\sim 3$ Ga quartz sandstones of Pilbara and Kaapvaal cratons, as well as in the early Paleoproterozoic Huronian Supergroup of the Superior craton, Canada. "Bituminous nodules...occupy intergranular pore space... and contain remnants of radioactive detrital grains." (Dutkiewicz et al. 1998). The observation that radioactivity occurred in these quartz sandstones can be associated to the above described prebiotic synthesis experiment which shows formation of organic compounds with gamma radiation excitation on $\mathrm{CO}, \mathrm{N}_{2}$ and $\mathrm{H}_{2} \mathrm{O}$. Indeed, when $\left(\mathrm{CO}_{2}, \mathrm{CH}_{4}, \mathrm{~N}_{2}, \mathrm{H}_{2} \mathrm{O}\right)$ fluid inclusions are located in appropriate distances of radioactive rocks, gamma emission can most probably excite the gaseous mixture and lead to the synthesis of macromolecules composed of amino acids. The yellow-brown product that is observed with proton irradiation (Kobayashi et al. 1998; Bassez et al. 2012 ) is most probably the same with gamma radiation, since the $G$-value of glycine is the same for $3 \mathrm{MeV}$ proton and low-dose rate gamma rays. Thus, these inclusions may have been a cradle for the formation of macromolecules of amino acids which were dissolved in the aqueous fluid or aggregated by heat as in an experiment conducted at $300{ }^{\circ} \mathrm{C}$ by Kurihara et al. (2012).

\section{Conclusion on Geobiotropy inside Fluid Inclusions}

Therefore, both heat and gamma ray excitation can lead to the formation of prebiotic molecules inside fluid inclusions, when $\mathrm{N}_{2}$ is present. At $\sim 350^{\circ} \mathrm{C}$, hydrogenation of $\mathrm{CO}_{2}$ produces $\mathrm{CO}$ and hydrogenation of $\mathrm{CO}$ produces $\mathrm{CH}_{4}$. The intermediate $\mathrm{CO}$ between $\mathrm{CO}_{2}$ and $\mathrm{CH}_{4}$ is usually not mentioned. However, it is important to notice that $\mathrm{CO}$ can be present and trigger the prebiotic syntheses cited above, as in Sabatier-Senderens/FischerTropsch combined to Haber-Bosch reactions or in excitation by the particles of interaction (as gamma rays) and matter (as helium nuclei) contained in cosmic radiation. Nitrogen is present in crustal rocks and may originate either from the atmosphere or from volcanic processes. Many ammonium-bearing minerals are known (Berg et al. 2016). An analysis of nitrogen in fluid inclusions trapped inside quartz of the 3.0-3.5 Ga Dresser Formation, Warraoona Group in the North Pole Dome area of Pilbara craton, Western Australia, concludes that "the partial pressure of $\mathrm{N}_{2}$ of the Archean atmosphere was lower than 1.1 bar, possibly as low as 0.5 bar" (Marty et al. 2013). Modern $\mathrm{pN}_{2}$ is $\sim 0.8$ bar. Many natural inclusions with various amounts of $\mathrm{CO}_{2}, \mathrm{CH}_{4}, \mathrm{H}_{2}, \mathrm{~N}_{2}, \mathrm{H}_{2} \mathrm{O}$ are observed. $\mathrm{CO}$ may form by hydrogenation of $\mathrm{CO}_{2}$, and $\mathrm{CH}_{4}$ may form through Sabatier-Senderens or Fischer- 
Tropsch reactions of $\mathrm{CO}$ and $\mathrm{H}_{2}$, both hydrogenations occurring at approximately the same temperature depending on the catalysts. As shown by Sabatier and Senderens (1902) the amount of $\mathrm{CO}$ versus $\mathrm{CH}_{4}$ depends very much on the relative abundance of $\mathrm{CO}_{2}$ and $\mathrm{H}_{2}$ and on the catalysts. Therefore, observations of inclusions with $\mathrm{CO}_{2}, \mathrm{CH}_{4}, \mathrm{~N}_{2}, \mathrm{H}_{2} \mathrm{O}$, mean that $\mathrm{H}_{2}$ and $\mathrm{CO}$ were present earlier and that prebiotic molecules of biological interest such as macromolecules of amino acids could form. Such inclusions may be located near radioactive rocks or not, inside the chert siderite and hematite of the BIFs. The mineral stilpnomelane, $\mathrm{K}\left(\mathrm{Fe}^{\mathrm{II}}, \mathrm{Mg}, \mathrm{Fe}^{\mathrm{III}}\right)_{8}(\mathrm{Si}, \mathrm{Al})_{12}(\mathrm{O}, \mathrm{OH})_{27}$, observed in $\mathrm{BIFs}$, contains the element potassium and consequently the radioactive isotope ${ }^{40} \mathrm{~K}$, with a half-life of $1.25 \mathrm{Ga}$, which desintegrates into the excited ${ }^{40} \mathrm{Ar} *$ argon, which returns to its ground state ${ }^{40} \mathrm{Ar}$ with emission of a $1.46 \mathrm{MeV}$ gamma radiation. Nitrogen containing organic matter could be searched in the environment of stilpnomelane. And since the formation of organic matter requires carbon from carbon dioxide, the search for prebiotic organic matter requires also locations where carbonates, siderite, or carbon which can be remnant of siderite, are present.

As a conclusion, Fig. 1 gives a summary for the above proposed synthesis of the minerals observed in BIFs and most probably in other hydrothermal silicate rocks, and for the prebiotic chemistry which can occur in symbiosis with the synthesis of ferric compounds, to form macromolecules of amino-acids. I place the emphasis on the consideration of the T\&P values of high-subcritical water, which can generate high silica dissolution and oxidation of $\mathrm{Fe}^{\mathrm{II}}$ into $\mathrm{Fe}^{\mathrm{III}}$ at high $\mathrm{pH}$, followed by the hydrolysis of fayalite which leads to the release of $\mathrm{H}_{2} \cdot \mathrm{CO}_{2}$ and $\mathrm{H}_{2}$ react also at the T\&P values of high-subcritical water to trigger the formation of $\mathrm{CO}$ and organic molecules. $\mathrm{H}_{2}$ is the link between geochemistry and organic chemistry in the process of geobiotropy where the rock evolves towards organic molecules of biological interest in an environment of anoxic high-subcritical water.

\section{Geobiotropy at T \& P of high subcritical water}

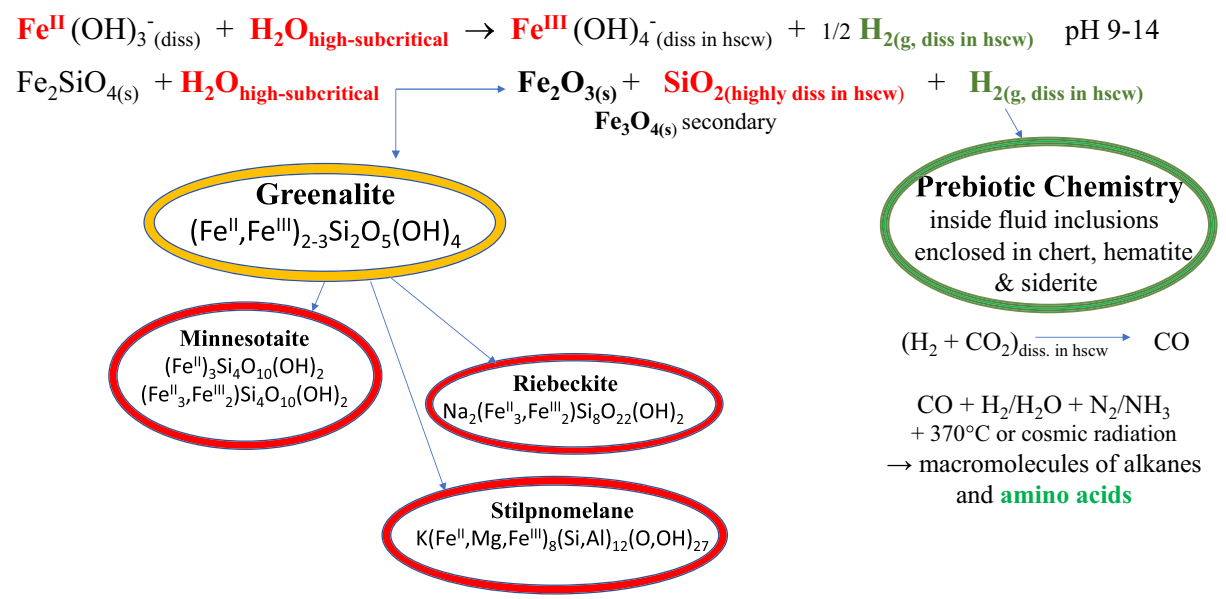

Fig. 1 The process of geobiotropy in anoxic alkaline high-subcritical water, showing the oxidation of ferrous iron into ferric iron, the hydrolysis of fayalite connected to the high dissolution of silica, and the release of $\mathrm{H}_{2}$. Hematite is a primary product, while magnetite is secondary. $\mathrm{Fe}^{\mathrm{III}}$-greenalite and its dehydrated $\mathrm{Fe}^{\mathrm{III}}$-silicates are produced when water is super-saturated in $\mathrm{SiO}_{2}$. Prebiotic chemistry is triggered by the release of $\mathrm{H}_{2}$ and the formation of $\mathrm{CO}$ in $\mathrm{T} \& \mathrm{P}$ conditions of high-subcritical water. Diss = dissolved, hscw $=$ high-subcritical water 


\section{Experimental Preliminary Results}

A first set of analyses is undertaken on a sample from the $899 \mathrm{~m}$ long BARB3 ICDP drill core in the 3.4 Ga old Buck Reef Chert of the Barberton Greenstone Belt, South Africa (Arndt et al. 2012, Hofmann et al. 2013). I choosed this Archean rock for the current certainty that no oxygen was present neither in the atmosphere nor in the oceans at the age of formation which is far away from the Great Oxidation Event. I conducted the analyses on March $22^{\text {nd }}, 2018$, in the department of Geology of the University of Johannesburg, with the thin section 23B that Axel Hofmann very kindly provided, and with a Raman Lab Witec Alpha300 instrument composed of a confocal microscope coupled to a Raman spectrograph. The excitation radiation is emitted from a Nd-YAG laser operating at the green $532 \mathrm{~nm}$ wavelength. The spectrum of Fig.2 is obtained with a laser power of $2.5 \mathrm{~mW}$ measured at the sample and it is collected with a 600 grooves $/ \mathrm{mm}$ grating. The acquisition time is 10 times $1 \mathrm{~s}$. The thin section has not been carbon coated.

I assign the spectrum of Fig.2 to $\alpha$-quartz and siderite as follows. Wavenumbers values are obtained with the graph software of the Witec Project version 6. They are compared mainly to the RRUFF (2018) spectra and raw data which were obtained with a $532 \mathrm{~nm}$ laser. The Raman-active

a)

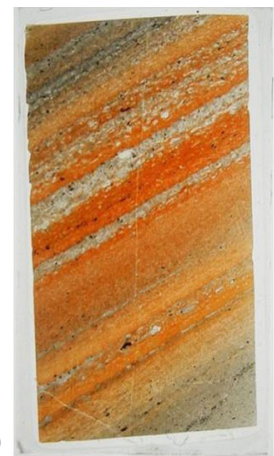

b)

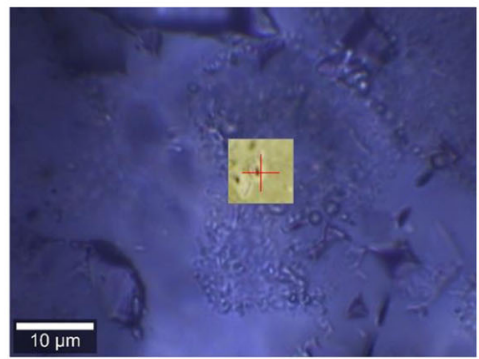

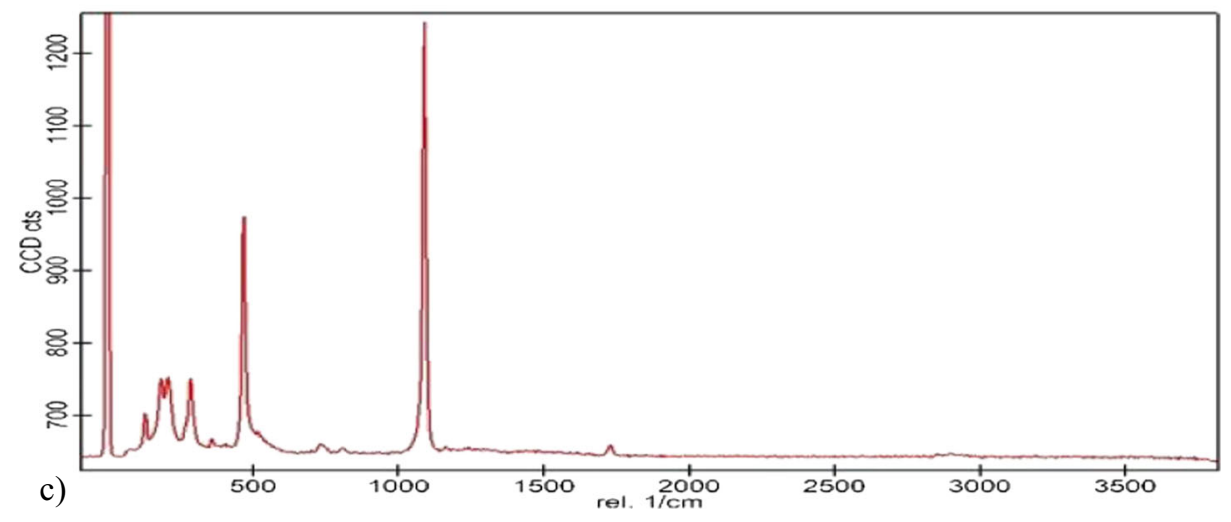

Fig. 2 a The polished thin section 23B $(2 \mathrm{~cm} \times 4 \mathrm{~cm} \times 30 \mu \mathrm{m})$ of a sample from the BARB3 drill core through Buck Reef Chert (easting 36 J 292202.67 northing 7,130,634.87; i.e. $25^{\circ} 55.685^{\prime} \mathrm{S} 30^{\circ} 55.511^{\prime} \mathrm{E}$ ) b) Image in Transmitted Light with the Witec alpha300 confocal microscope equipped with the objective $100 \times$ c) Raman spectrum taken with the Witec spectrograph at the location of the red cross in b; the broad scan is between $-80 \mathrm{~cm}^{-1}$ et $+3800 \mathrm{~cm}^{-1}$; laser light: $532 \mathrm{~nm}$ 
modes A and E are assigned mainly with the help of Nasdala et al. (2004), Rousseau et al. (1981), Kingma and Hemley (1994), Blanchard et al. (2009), Boulard et al. (2012), and refs herein.

Sixteen Raman-active vibrations of $\alpha$-quartz are described in Kingma and Hemley (1994) with their corresponding $\mathrm{A}$ and $\mathrm{E}$ modes. The RRUFF (n.d.) spectrum of quartz from Bergamo, B, shows 13 of them. They are described in Table 3 with their relative intensities within parentheses. Despite the fact that Raman-active vibrations may have strong directional dependence (Nasdala et al. 2004) several of the Bergamo $\alpha$-quartz Raman modes are recognized in the Buck Reef Chert, BRC, sample considering both wavenumbers and relative intensities (Fig. 2 and Table 3). The strongest BRC peak at $468 \mathrm{~cm}^{-1}$ is assigned to the $\alpha$-quartz Raman mode $\mathrm{A}_{1}$ which corresponds to the symmetric Si-O-Si stretching vibration. The $\mathrm{B}$ $510 \mathrm{~cm}^{-1}$ is hidden at the base of the BRC $468 \mathrm{~cm}^{-1}$ which appears asymmetrical. The $1069 \mathrm{~cm}^{-1} \mathrm{E}$ mode of $\alpha$-quartz (not in Bergamo but described in Kingma and Hemley 1994) and the B $1083 \mathrm{~cm}^{-1}$ are overlapped by the strong siderite $1090 \mathrm{~cm}^{-1}$ mode $\mathrm{A}_{1 \mathrm{~g}}$.

The identification of the other lines of the Buck Reef Chert sample, as shown in Table 3, are based mainly on the Raman RRUFF (n.d.) spectrum of a Connecticut, C, siderite which is the siderite RRUFF (n.d.) sample with the highest content in Fe. Wavenumbers and relative intensities match very well. Wavenumbers correspond also to those of the Raman-active modes $A_{1 g}$ (symmetric single vibration or single degenerate) and $E_{g}$ (doubly degenerate) of siderite, described in Blanchard et al. (2009). The peak of very low intensity at $736 \mathrm{~cm}^{-1}$ corresponds to the Raman mode Eg of the bending vibration in the plane of the $-\mathrm{CO}_{3}$ group. It appears slightly asymmetrical as expected for Fe-bearing carbonates (Boulard et al. 2012). The strong peak at $1090 \mathrm{~cm}^{-1}$ is due to the symmetric in-plane stretching vibration of the $-\mathrm{CO}_{3}$ group which appears as the Raman mode $\mathrm{A}_{1} \mathrm{~g}$. The mode $\mathrm{Eg}$ of the asymmetric stretching vibration, which appears between 1442 and $1446 \mathrm{~cm}^{-1}$ in the Raman spectra of carbonates, as for smithsonite $\mathrm{ZnCO}_{3}$ and spherocobaltite $\mathrm{CoCO}_{3}$, is not detected in BRC. Since this mode of vibration is of very low

Table 3 Assignment of the Raman spectrum of the Buck Reef Chert sample 23B, of Fig.2

\begin{tabular}{|c|c|c|c|}
\hline \multicolumn{3}{|c|}{ Raman wavenumbers $\mathrm{cm}^{-1}$} & \multirow[t]{2}{*}{ Raman modes } \\
\hline Buck Reef Chert * & Bergamo $\alpha$-quartz $*$ & Connecticut siderite $*$ & \\
\hline $130(3)$ & $129(19)$ & & $\mathrm{E}$ \\
\hline $188(5)$ & & $185(4)$ & $E_{g}$ \\
\hline \multirow[t]{2}{*}{$207(5)$} & $207(18)$ & & $\mathrm{A}_{1}$ \\
\hline & $267(3)$ & & $\mathrm{E}$ \\
\hline $286(5)$ & & $286(5)$ & $\mathrm{E}_{\mathrm{g}}$ \\
\hline \multirow[t]{2}{*}{359 (1) } & $357(6)$ & & $\mathrm{A}_{1}$ \\
\hline & $395(1.5)$ & & $\mathrm{E}$ \\
\hline $405(0.2)$ & $404(1)$ & & $\mathrm{E}$ \\
\hline \multirow[t]{3}{*}{$468(20)$} & $466(73)$ & & $\mathrm{A}_{1}$ \\
\hline & $510(3)$ & & $\mathrm{E}$ \\
\hline & $697(0.6)$ & & $\mathrm{E}$ \\
\hline $736(1)$ & & $729(1)$ & $\operatorname{Eg}\left(v_{4}\right)$ \\
\hline \multirow[t]{2}{*}{$809(0.5)$} & $810(3)$ & & $\mathrm{E}$ \\
\hline & $1083(2)$ & & $\mathrm{A}_{1}$ \\
\hline $1090(37)$ & & $1086(29)$ & $A_{1 g}\left(v_{1}\right)$ \\
\hline \multirow[t]{2}{*}{$1165(0.1)$} & $1161(1)$ & & $\mathrm{E}$ \\
\hline & $1233(0.2)$ & & $\mathrm{E}$ \\
\hline $1730(1)$ & & $1728(1)$ & $v_{1}+v_{4}$ \\
\hline
\end{tabular}

*The values within parentheses indicate the relative intensities of the peaks, that I calculated in their own spectrum. In order to compare the intensities of Buck Reef Chert with Bergamo quartz, it is necessary to multiply the BRC values by 5 
intensity in the case of Fe-rich carbonates (Boulard et al. 2012), the absence of this peak confirms the detection of siderite. Finally, the low intensity peak at $1730 \mathrm{~cm}^{-1}$ corresponds to a combination of the $\mathrm{A}_{1 \mathrm{~g}}$ symmetric stretching with the $\mathrm{E}_{\mathrm{g}}$ bending mode in the plane of the $\mathrm{CO}_{3}$ group.

The Buck Reef Chert $405 \mathrm{~cm}^{-1}$ could indicate the presence of hematite (Hanesch 2009; Oh et al. 1998). However, neither the strong peak of hematite at $\sim 1320 \mathrm{~cm}^{-1}$ nor the medium peaks at $225 \mathrm{~cm}^{-1}$ and $\sim 295 \mathrm{~cm}^{-1}$ are present. Another weak and broad band appears centered at $2902 \mathrm{~cm}^{-1}$. It is the region of C-H stretching vibrations. More investigations are needed. Therefore, the analyzed location of the Buck Reef Chert sample shows the presence of crystalline $\alpha$-quartz and siderite. Amorphous silica is absent. Another location of the colorful thin section will most probably show signs of hematite, which in association with quartz and siderite, can be at the origin of prebiotic molecules as described above.

\section{Conclusion}

With this article, I try to set the emphasis on the state of water which is basic (pH 9.5-14) and high-subcritical $\left(300{ }^{\circ} \mathrm{C}-350{ }^{\circ} \mathrm{C}, 10-25 \mathrm{MPa}\right)$. I show that these conditions transform ferrous iron into ferric iron in the absence of oxygen and that $\mathrm{Fe}^{\mathrm{III}}$-oxides and $\mathrm{Fe}^{\mathrm{III}}$-silicates are synthesized. This anoxic synthesis of $\mathrm{Fe}^{\mathrm{III}}$-compounds is applied to the minerals of Banded Iron Formations in an attempt to explain their origin. The interaction between basic silicaundersaturated hsc water and fayalite/ferrosilite at depth inside the Earth crust can lead to the minerals of BIFs. Hematite is a primary product while magnetite is secondary. Fe $\mathrm{III}^{\mathrm{II}}$-greenalite is a primary product as minnesotaite and possibly riebeckite and stilpnomelane. The formation of amorphous silica versus crystalline quartz is dependent upon this high-subcritical state of water and its $\mathrm{pH}$. The type of minerals which forms depends on the content in silica. In high silica content, the $\mathrm{Fe}^{\mathrm{III}}$-greenalite dehydrated products such as minnesotaite, stilpnomelane, riebeckite may dominate and incorporate ferric iron.

In the above chapter on the formation of BIFs, I concluded in the necessity of water showing four characteristics at a specific kairos in space and time: high-subcritical state, high $\mathrm{pH}$, undersaturated in silica and interacting with iron-olivine and -pyroxenes. As a global conclusion for the formation of BIFs and molecules of life inside fluid inclusions, I introduce now the necessity of four chemical processes which all occur in high-subcritical water. First, at highsubcritical conditions of water, and not above, ferrous iron transforms into ferric iron with release of $\mathrm{H}_{2}$ at high $\mathrm{pH}$. This is observed from E-pH diagrams. Second, also at high-subcritical conditions of water, and not above, silica dissolves in water. This is observed from a solubility diagram showing a transition at the critical point of water. The third process is the interaction of silicaundersaturated hscw with $\mathrm{Fe}^{\mathrm{II}}$-silicates to produce the ferric compounds of $\mathrm{BIFs}$ and $\mathrm{H}_{2}$, and the fourth process is the hydrogenation of $\mathrm{CO}_{2}$ in hscw to produce $\mathrm{CO}$, an essential molecule for prebiotic synthesis. In their interaction with silica-undersaturated hscw, $\mathrm{Fe}^{\mathrm{II}}$-silicates produce silica. Near supercritical water can thus become supersaturated in silica and dehydration of the hydrolysis product, greenalite, can proceed into minnesotaite. The hydrolyses of fayalite and ferrosolite in carbonated near-supercritical water lead to the main products, ferric hydroxide, hematite, silica, siderite, greenalite and minnesotaite, which are the minerals of the banded iron formations. Further dehydration can most probably lead to riebeckite and stilpnomelane. And magnetite can form in the transformation of siderite. Silica which is formed at these T\&P near $374{ }^{\circ} \mathrm{C}$ and $22 \mathrm{MPa}$ and then quenched in cool ocean water can be structured as a glass. As a consequence, water near its supercritical point shows properties which trigger two effects complementing each other: the 
formation of ferric compounds and of dissolved silica leading to dehydrated ferric silicates. Following the emission of $\mathrm{H}_{2}$ in the hscw-rock interaction, the formed $\mathrm{CO}$ can react at the same temperature with $\mathrm{H}_{2}$ and $\mathrm{N}_{2} / \mathrm{NH}_{3}$ to form molecules of biological interest such as aggregates of amino-acids which are synthesized in the above described laboratory experiments.

Therefore, anoxic alkaline water in its high-subcritical state appears, to my knowledge, as an essential component for the chemical synthesis of minerals in Banded Iron Formations and for the connected geobiotropic chemistry inside fluid inclusions.

Acknowledgements I warmly thanks Michel Cuney, Directeur de Recherches CNRS, Dr. Julien Mercadier, Dr. Antonin Richard, GeoRessources, le laboratoire de recherche en Géologie, et le CREGU, centre de recherches sur la Géologie des Matières Premières Minérales et Energétiques, Université de Lorraine, Nancy, France, for the interest they show in my hypothesis of formation of prebiotic molecules inside fluid inclusions and my concept of geobiotropy.

I am warmfully grateful to Professor Axel Hofmann, department of Geology, University of Johannesburg, South-Africa who considered innovative my idea of ferric iron production in Archean geological times in a context of anoxic, high $\mathrm{pH}$, high-subcritical water, and consequently lent his personal thin sections of BARB3 drill cores and the Raman spectroscopic instrument for the search of prebiotic matter with the perspective of "following the hematite". I also thank sincerely Dr. Andrea Agangi for his practical advises in the experimental calibration of the Raman spectrometer. My acknowledgements are also addressed to Professor Nicolas J Beukes who kindly considered my research very "basic" and Dr. Stephanus J. Krüger for the gift of thin sections from the BARB4 drill cores and his positive consideration of my research.

It was a great pleasure to read the kind comments of the anonymous reviewer who induced improvements of the article.

Open Access This article is distributed under the terms of the Creative Commons Attribution 4.0 International License (http://creativecommons.org/licenses/by/4.0/), which permits unrestricted use, distribution, and reproduction in any medium, provided you give appropriate credit to the original author(s) and the source, provide a link to the Creative Commons license, and indicate if changes were made.

\section{References}

Adschiri T, Kanazawa K, Arai K (1992) Rapid nad continuous hydrothermal crystallization of metal oxide particle in supercritical water. J Am Ceram Soc 75(4):1019-1022

Alonso-Domínguez D, Alvarez-Serrano I, Pico MP, Lopez ML, Urones-Garrote E, Pico C, Veiga ML (2017) Nanoparticulated spinel-type iron oxides obtained in supercritical water and their electrochemical performance as anodes for li ion batteries. J Alloys Compd 695:3239-3248

Anthony JW, Bideaux RA, Bladh KW, Nichols MC (2004-2017) Handbook of mineralogy, Mineralogical Society of America, Chantilly, VA 20151-1110, USA. http://www.handbookofmineralogy.org/

Arakcheeva A, Bindi L, Pattison P, Meisser N, Chapuis G, Pekov I (2010) The incommensurately modulated structures of natural natrite at 120 and $293 \mathrm{~K}$ from synchrotron X-ray data. Am Mineral 95:574-581

Arndt NT, Wilson A, Hofmann A, Mason P, Bau M, Byerly G, Chunnett G (2012) Peering into the cradle of life: scientific drilling in the Barberton Greenstone Belt. Sci Drill 13:71

Baes Jr CF, Mesmer RE (1976) The hydrolysis of cations. Wiley eNew-York, 489p

Barnes I, LaMarche VC Jr, Himmelberg G (1967) Geochemical evidence of present-day serpentinization. Science 156:830-832

Bassez MP (1971) Contribution à l'étude par spectroscopie électronique et résonance paramagnétique électronique des réactions de l'azote activé sur des éléments du groupe VI B. Ph.D. Thesis, Université des Sciences et Techniques de Lille, Fr

Bassez MP (1998-2018) La Vie, ses origines, sa biodiversité. Université de Strasbourg. http://chemphys.ustrasbg.fr/mpb/teach/originevie.html open and e-book Chemphys

Bassez MP (2003) Is high-pressure water the cradle of life? J Phys Condens Matter 15(24):L353-L361

Bassez MP (2008) Synthèse prébiotique hydrothermale. Proc CNRIUT'2008, Lyon, Fr http://iris.cnrs. $\mathrm{fr} / \sim$ cnriut08/actes/ access 29May/C open

Bassez MP (2009a) Prebiotic synthesis under hydrothermal conditions. Orig Life Evol Biosph 39(3-4):179-392 p223-225 
Bassez MP (2009b) Synthèse prébiotique dans les conditions hydrothermales. C R Chim 12(6-7):801-807

Bassez MP (2013) Geochemical origin of biological molecules. EGU'2013:Vienna, Austria, Session: Planetary \& Solar System Sciences/Origins and Astrobiology/Planetary Evolution and Life/PS8.1, Oral:Tues. April 9th/ 9h30, EGU2013-22. Geophysical Research Abstracts Vol 15, EGU2013-22 http://meetingorganizer. copernicus.org/EGU2013/EGU2013-22.pdf open

Bassez MP (2015) Water, air, earth and cosmic radiation. Orig Life Evol Biosph 45(1):5-13

Bassez MP (2016a) Geobiotropy. LPSC'2016, The Woodlands, US. Abstr \#1853 http://www.hou.usra. edu/meetings/lpsc2016/pdf/1853.pdf open

Bassez MP (2016b) * Geobiotropy: the evolution of rocks as sign of components of life. EANA'2016-Athens, 27-30-Sept. * Ferromagnesian silicate and ferrosulfide rocks as a source of magnetite and hydrogen. WRI15, Evora, 16-21 Oct.. Two conferences deposited on: http://chemphys.u-strasbg.fr/mpb/teach/originevie. html La Géobiotropie

Bassez MP (2017a) WRI-15. Procedia earth and planetary science 17, 492-495 open

Bassez MP (2017b) Anoxic and oxic oxidation of rocks containing Fe(II)Mg-silicates and Fe(II)-monosulfides as a source of Fe(III)-minerals and hydrogen; Geobiotropy. Orig Life Evol Biosph 47:453-480

Bassez MP, Takano Y, Kobayashi K (2012) Prebiotic organic microstructures. Orig Life Evol Biosph 42:307-316 open

Bénézeth P, Dandurand JL, Harrichoury JC (2009) Solubility procuct of siderite $\left(\mathrm{FeCO}_{3}\right)$ as a function of temperature $\left(25^{\circ} \mathrm{C}-250^{\circ} \mathrm{C}\right)$. Chem Geol $265: 3-12$

Berg BL, Cloutis EA, Beck P, Vernazza P, Bishop JL, Takir D, Reddy V, Applin D, Mann P (2016) Reflectance spectroscopy $(0.35-8 \mu \mathrm{m})$ of ammonium-bearing minerals and qualitative comparison to Ceres-like asteroids Icarus 265:218-237

Berthelot M (1868) Union de l'azote libre avec l'acétylène; synthèse directe de l'acide cyanhydrique. Comptes Rendus 67:1141-1145

Bertone JF, Cizeron J, Wahi RK, Bosworth JK, Colvin VL (2003) Hydrothermal synthesis of quartz nanocrystals. Nano Lett 3(5):655-659

Beukes NJ (1984) Sedimentology of the Kuruman and Griqualand iron-formations, Transvaal Supergroup, Griqualand west, South Africa. Precambrian Res 24:47-84

Beukes NJ, Gutzmer J (2008) Origin and Paleoenvironmental significance of major iron formations at the archean-paleoproterozoic boundary. Soc Econ Geol Rev 15:5-47

Biermann M, Bardi B, Vollstädt S, Linnemann J, Knüpfer U, Seidel G, Horn U (2013) Simultaneous analysis of the non-canonical amino acids norleucine and norvaline in biopharmaceutical-related fermentation processes by a new ultra-high performance liquid chromatography approach. Amino Acids 44(4):1225-1231

Blades H, Winkler CA (1951) The reaction of nitrogen atoms with methane and ethane. Can J Chem 20:10221027

Blanchard M, Poitrasson F, Méheut M, Lazzeri M, Mauri F, Balan E (2009) Iron isotope fractionation between pyrite $\left(\mathrm{FeS}_{2}\right)$, hematite $\left(\mathrm{Fe}_{2} \mathrm{O}_{3}\right)$ and siderite $\left(\mathrm{FeCO}_{3}\right)$ : a first-principles density functional theory study. Geochim Cosmochim Acta 73:6565-6578

Bontognali TRR, Fischer WW, Föllmi KB (2013) Siliciclastic associated banded iron formation from the $3.2 \mathrm{Ga}$ Moodies group, Barberton Greenstone Belt, South Africa. Precambrian Res 226:116-124

Boulard E, Guyot F, Fiquet G (2012) The influence on Fe content on Raman spectra and unit cell parameters of magnesite-siderite solid solutions. Phys Chem Miner 39(3): 239-246. https://doi.org/10.1007/s00269-0110479-3

Brückner H, Becker D, Gams W, Degenkolb T (2009) Aib and Iva in the biosphere: neither rare nor necessarily extraterrestrial. Chem Biodivers 6(1):38-56

Byrappa K, Adschiri T (2007) Hydrothermal technology for nanotechnology. Prog Cryst Growth Charact Mater 53:117-166

Cairns-Smith (1978) Precambrian solution photochemistry, inverse segregation, and banded iron formations. Nature 76:807-808

Chen CS, Cheng WH, Lin SS (2000) Mechanism of CO formation in reverse water-gas shift reaction over cu/ $\mathrm{Al}_{2} \mathrm{O}_{3}$ catalyst. Catal Lett $68: 45-48$

Condie K (2016) A planet in transition: the onset of plate tectonics on earth between 3 and 2 Ga? Geosci Front. https://doi.org/10.1016/j.gsf.2016.09.001

Condie KC, Aster RC, van Hunen J (2016) A great thermal divergence in the mantle beginning $2.5 \mathrm{Ga}$ geochemical constraints from greenstone basalts and komatiites. Geosci Front 7:543-553

Cook GW, Olive PR (2012) Pourbaix diagrams for the iron-water system extended to high \& low supercritical conditions. Corros Sci 55:326-331

Cornell RM, Schwertmann U (2003/2006) The Iron oxides: structure, properties, reactions, occurrences and uses. Wiley-VCH, Weinheim

Cronin JR, Pizzarello S (1997) Enantiomeric excesses in meteoritic amino acids. Science 275:951-955 
Daval D, Testemale D, Recham N, Tarascon JM, Siebert J, Martinez I, Guyot F (2010) Fayalite $\left(\mathrm{Fe}_{2} \mathrm{SiO}_{4}\right)$ dissolution kinetics determined by X-ray absorption spectroscopy. Chem Geol 275:161-175

Dekkers MJ (1990) Magnetic properties of natural goethite: III. Magnetic behaviour and properties of minerals originating from goethite dehydration during thermal demagnetization. Geoph J Int 103:233-250

Dumas A, Claverie M, Slostowski C, Aubert G, Careme C, Le Roux C, Micoud P, Martin F, Aymonier C (2016) Fast-Geomimicking using chemistry in supercritical water. Angewandte Chemie Int Ed 128:10022-10025

Dutkiewicz A, Rasmussen B, Buick R (1998) Oil preserved in fluid inclusions in Archean sandstones. Nature 395(29):885-888

Eugster HP, Chou IM (1973) The depositional environments of Precambrian banded iron-formations. Econ Geol 68:1144-1168

Eugster HP, Jones BF (1968) Gels composed of sodium-aluminium silicate, lake Magadi, Kenya. Science 161(3837):160-163. https://doi.org/10.1126/science.161.3837.160

Faivre D (2016) Iron oxides. From nature to applications. Wiley-VCH, Weinheim

Fournier RO, Rowe JJ (1977) The solubility of amorphous silica in water at high temperatures and high pressures. Am Mineral 62:1052-1056

French BM, Rosenberg PE (1965) Siderite $\left(\mathrm{FeCO}_{3}\right)$ : Thermal decomposition in equilibrium with graphite. Science 147:1283-1284

Fu Q, Seyfried Jr WE (2009) Experimental study of abiotic synthesis processes in a hydrothermal flow system. LPSC'2009, The Woodlands. Abstr \#2504

Glavin DP, Dworkin JP (2009) Enrichment of the amino acid L-isovaline by aqueous alteration on CI and CM meteorite parent bodies. PNAS 106(14):5487-5492

Grozeva NG, Klein F, Seewald JS, Sylva SP (2017) Experimental study of carbonate formation in oceanic peridotite. Geochim Cosmochim Acta 199:264-286

Guggenheim S, Eggleton RA (1998) Modulated crystal structures of greenalite and caryopilite: a system with long-range, in-plane structural disorder in the tetrahedral sheet. Can Mineral 36:163-179

Hanesch M (2009) Raman spectroscopy of iron oxides and (oxy)hydroxides at low laser power and possible applications in environmental magnetic studies. Geophys J Int 177:941-948

Hassenkam T, Andersson MP, Dalby KN, Mackenzie DMA, Rosing MT (2017) Elements of Eoarchean life trapped in mineral inclusions. Nature 548(3):78-81

Haugaard R, Pecoits E, Lalonde S, Rouxel O, Konhauser K (2016) The Joffre banded iron formation, Hamersley group, Western Australia: assessing the paleoenvironment through detailed petrology and chemostratigraphy. Precambrian Res 273:12-37

Hill HGM, Nuth J (2003) The catalytic potential of cosmic dust: implications for prebiotic chemistry in the solar nebula and other protoplanetary systems. Astrobiology 3(2):291-304

Hodgkinson MRS (2015) The geological controls on the Von Damm vent field. PhD Thesis, University of Southampton, School of Ocean and Earth Science

Hodgkinson MRS, Webber AP, Roberts S, Mills RA, Connelly DP, Murton BJ (2015) Talc-dominated seafloor deposits reveal a new class of hydrothermal system. Nat Commun 6:10150. https://doi.org/10.1038 /ncomms 10150

Hofmann A, Karykowski B, Mason P, Chunnet G, Arndt N (2013) Barberton drilling project-Buck reef Chert core BARB3. Geophys Res Abstr 15:EGU2013-EG12227

Holm N (1996) Serpentinization of oceanic crust and Fischer-Tropsch type synthesis of organic compounds. Origins Life Evol Biospheres 26(3-5):205-206

Hurai V, Huraiova M, Slobodnik M, Thomas R (2015) Geofluids. Developments in microthermometry, spectroscopy. Thermodynamics, and stable isotopes. Elsevier Inc

Johnson JE, Muhling JR, Cosmidis J, Rasmussen B, Templeton AS (2018) Low-Fe(III) greenalite was a primary mineral from Neoarchean oceans. Geophys Res Lett 45. https://oi.org/10.1002/2017GL076311

Karasek P, Stavikova L, Planeta J, Hohnova B, Roth M (2013a) Solubility of fused silica in sub- and supercritical water: estimation from a thermodynamic model. J Supercrit Fluids 83:72-77

Karasek P, Planeta J, Roth M (2013b) Near- and supercritical water as a diameter manipulation and surface roughening agent in fused silica capillaries. Anal Chem 85:327-333

Kelley D (1996) Methane-rich fluids in the oceanic crust. J Geophys Res 101(B2):2943-2962

Khomyakov AP (1983) Natrite, $\mathrm{Na}_{2} \mathrm{CO}_{3}$-a new mineral. Int Geol Rev 25(9):1111-1116

Kingma KJ, Hemley R (1994) Raman spectroscopic study of microcrystalline silica. Am Mineral 79: 269-273

Klein F, Grozeva NG, Seewald JS, McCollom MT, Humphris ES, Moskowitz B, Berquo ST, Kahl WA (2015) Experimental constraints on fluid-rock reactions during incipient serpentinzation of harzburgite. Am Mineral 100:991-1002

Klein ZB, Jagoutz O, Behn DM (2017) Archean crustal compositions promote full mantle convection. Earth Planet Sci Lett 474: 516-526 
Kobayashi K, Tsuchiya M, Oshima T, Yanagawa H (1990) Abiotic synthesis of amino acids and imidazole by proton irradiation of simulated primitive earth atmospheres. Orig Life Evol Biosph 20:99-109

Kobayashi K, Kaneko T, Saito T, Oshima T (1998) Amino acid formation in gas mixtures by high energy particle irradiation. Orig Life Evol Biosph 28:155-165

Kobayashi K, Ogawa T, Tonishi H, Kaneko T, Takano Y, Takahashi JI, Saito T, Muramatsu Y, Yoshida S, Utsumi Y (2008) Synthesis of amino acid precursors from simulated interstellar media by high-energy particles or photons. Electron Commun Japan 91(3):15-21

Kurihara H, Yabuta H, Kaneko T, Obayashi Y, Takano Y, Kobayashi K (2012) Characterization of organic aggregates formed by heating products of simulate primitive earth atmosphere experiments. Chem Lett 41: 441-443. https://doi.org/10.1246/cl.2012.441

Lamadrid HM, Rimstidt JD, Schwarzenbach EM, Klein F, Ulrich S, Dolocan A, Bodnar RJ (2017) Effect of water activity on rates of serpentinization of olivine. Nat Commun 8:16107. https://doi.org/10.1038 /ncomms16107 (2017) open(2017) open"/>

Liebscher A (2010) Aqueous fluid at elevated pressure and temperature. Geofluids 10:3-19

Loring JS, Schaef HT, Turcu RVF, Thompson CJ, Miller QRS, Martin PF, Hu JZ, Hoyt DW, Qafoku O, Ilton ES, Felmy AR, Rosso KM (2012) In situ molecular spectroscopic evidence for $\mathrm{CO}_{2}$ intercalation into montmorillonite in supercritical carbon dioxide. Langmuir 28(18):7125-7128

Macdonald DD (1992) Critical issues in the use of metals and alloys in sulphur-containing aqueous systems. Annual conference of metallurgists on materials performance, sulphur and energy, Edmonton, Ca, 24-27 August, https://www.osti.gov/scitech/biblio/6395030. OSTI 1993 report n 6395030 https://www.osti. gov/scitech/servlets/purl/6395030 diagrams shown at: http://chemphys.u-strasbg.fr/mpb/teach/originevie. html La Géobiotropie

Macdonald DD, Hettiarachchi S, Song H, Maleka K, Emerson R, Ben-Haim M (1992) Measurement of pH in subcritical and supercritical aqueous systems. J Solut Chem 21(8):849-881

Malvoisin B, Brunet F, Carlut J, Rouméjon S, Cannat M (2012) Serpentinization of oceanic peridotites: 2. Kinetics and processes of San Carlos olivine hydrothermal alteration. J Geophys Res 117:B04102, 1-13, https://doi.org/10.1029/2011JB008842

Manning CE (1994) The solubility of quartz in $\mathrm{H}_{2} \mathrm{O}$ in the lower crust and upper mantle. Geochim Cosmochim Acta 58(22):4831-4839

Marty B, Zimmermann L, Pujol M, Burgess R, Philippot P (2013) Nitrogen isotopic composition and density of the Archean atmosphere. Science 342:101-104

McDermott, JM (2015) Geochemistry of deep-sea hydrothermal vent fluids from the Mid-Cayman Rise, Carribean Sea. PhD thesis, Massachusetts Institute of Technology \& Woods Hole Oceanographic Institution

McDermott JM, Seewald JS, German CR, Sylva SP (2015) Pathways for abiotic organic synthesis at submarine hydrothermal fields. PNAS 112(25):7668-7672

Milesi V, Guyot F, Brunet F, Richard L, Recham N, Benedetti M, Dairou J, Prinzhofer A (2015) Formation of $\mathrm{CO}_{2}, \mathrm{H}_{2}$ and condensed carbon from siderite dissolution in the $200-300^{\circ} \mathrm{C}$ range and at $50 \mathrm{MPa}$. Geochim et Cosmochim Acta 154:201-211

Moe LA (2013) Amino acids in the rhizosphere: from plants to microbes. Am J Bot 100(9):1692-1705

Moser RE, Claggett AR, Matthews CN (1968) Peptide formation from aminomalononitrile (HCN trimer). Tetrahedron Lett 9(13):1605-1608

Nasdala L, Smith DC, Kaindk R, Ziemann MA (2004) Raman spectroscopy: analytical perspectives in mineralogical research. in Spectroscopic methods in mineralogy eds Beran A \& Libowitzky E, European mineralogical union notes in mineralogy 6, chapter 7: 281-343

Oh SJ, Cook DC, Townsend HE (1998) Characterization of iron oxides commonly formed as corrosion products on steel. Hyperfine Interac 112:59-65. https://doi.org/10.1023/A:1011076308501

Olsson J, Bovet N, Makovicky E, Bechgaard K, Balogh Z, Stipp SLS (2012) Olivine reactivity with $\mathrm{CO}_{2}$ and $\mathrm{H}_{2} \mathrm{O}$ on a microscale: implications for carbon sequestration. Geochim et Cosmochim Acta 77:86-97

Pironon J, Richard A, Tarantola A, Caumon MC, Faure F, Ernest V (2017) Inclusions. ed. ASGA, association scientifique pour la géologie et ses applications

Pizzarello S (2012) Catalytic syntheses of amino acids and their significance for nebular and planetary chemistry. Meteorit Planet Sci 47(8):1291-1296

Posth NR, Hegler F, Konhauser KO, Kappler A (2018) Alternating Si and Fe deposition caused by temperature fluctuations in Precambrian oceans. Nat Geosci 1:703-708

PubChem Open Chemistry Data Base (2018) https://pubchem.ncbi.nlm.nih.gov/compound/sodium carbonate\#section=pH https://pubchem.ncbi.nlm.nih.gov/compound/ammonium_hydroxide\#section=pH

Qafoku O, Kovarik L, Kukkadapu RK, Ilton ES, Arey BW, Tucek J, Felmy AR (2012) Fayalite dissolution and siderite formation in water-saturated supercritical $\mathrm{CO}_{2}$. Chem Geol 332-333:124-135 
Rasmussen B, Krape B, Muhling JR (2014) Hematite replacement of iron-bearing precursor sediments in the 3.46-b.Y.-old marble bar Chert, Pilbara craton, Australia. Geol Soc Am Bull 126(9-10):1245-1258

Rasmussen B, Krapez B, Muhling JR, Suvorova A (2015) Precipitation of iron silicate nanoparticles in early Precambrian oceans marks Earth's first iron age. Geology 43(4):303-306. https://doi.org/10.1130/G36309.1

Rasmussen B, Muhling JR, Suvorova A, Krapez B (2017) Greenalite precipitation linked to the deposition of banded iron formations downslope a late Archean carbonate platform. Precambrian Res 290:49-62

Rauchfuss H (2008) Chemical evolution and the origin of life. Springer-Verlag, Berlin, Heidelberg

Robie RA, Hemingway BS (1995) Thermodynamic properties of minerals at $298.15 \mathrm{~K}$ and 1 bar $\left(10^{5} \mathrm{~Pa}\right)$. US Geological Survey Bull 2131

Rousseau DL, Bauman RP, Porto SP (1981) Normal mode determination in crystals. J Raman Spectrosc 10:253290

RRUFF (2018) Database of Raman spectra, X-ray diffraction and chemistry data for minerals. http://rruff.info

Rzepa G, Pieczara G, Gawel A, Tomczyk A (2016) The influence of silicate on transformation pathways of synthetic 2-line ferrihydite. J Therm Anal Calorim 125:407-421

Sabatier P, Senderens JB (1902) Hydrogénation directe des oxydes du carbone en présence de divers métaux divisés. Comptes rendus des séances hebdomadaires de l'académie des sciences 134:689-691

Schlesinger G, Miller SL (1983) Prebiotic synthesis in atmospheres containing $\mathrm{CH}_{4}, \mathrm{CO}$, and $\mathrm{CO}_{2}$. J Mol Evol 19:376-382

Seyfried WE Jr, Foustoukos ID, Fu Q (2007) Redox evolution and mass transfer during serpentinization. Geochim Cosmochim Ac 71:3872-3886

Shock EL, Helgeson HC, Sverjensky DA (1989) Calculation of the thermodynamic and transport properties of aqueous species at high pressures and temperatures: standard partial molal properties of inorganic neutral species. Geochim Cosmochim Acta 53:2157-2183

Siever R, Woodford N (1973) Sorption of silica by clay minerals. Geochim Cosmochim Acta 37:1851-1880

Sigg L, Stumm W (1981) The interaction of anions and weak acids with hydrous goethite $(\alpha-\mathrm{FeOOH})$ surface. Colloids Surf 2(2):101-117

Smith RL Jr, Fang Z (2011) Properties and phase equilibria of fluid mixtures as the basis for developing green chemical processes. Fluid Phase Equilib 302:65-73

Stein CL (1982) Silica recrystallization in petrified wood. J Sed Petrol 52:1277-1282

Tassaing T, Soetens JC, Vyalov I, Kiselev M, Idrissi A (2010) Supercritical ammonia: a molecular dynamics simulation and vibrational spectroscopic investigation. J Chem Phys 133:214505-1-214505-8

Taylor KG, Konhauser KO (2011) Iron in earth surface systems: a major player in chemical and biological processes. Elements 7:83-88

Tosca NJ, Guggenheim S, Pufahl PK (2016) An authigenic origin for Precambrian greenalite: Implications for iron formation and the chemistry of ancient seawater. GSA Bull 128(3-4):511-530

Trendall AF, Blockley JG (1970) The iron formations of the Hamersley group, Western Australia, with special reference to the associated crocidolite. Bull W Aust Geol Surv 119:353pp

Volosov AG, Khodakovskiy IL, Ryzhenko BN (1972) Equilibria in the system $\mathrm{SiO}_{2}-\mathrm{H}_{2} \mathrm{O}$ at elevated temperatures along the lower three-phase curve. Geochem Int 9:362-377

Walther JV, Helgeson HC (1977) Calculation of the thermodynamic properties of aqueous silica and the solubility of quartz and its polymorphs at high pressures and temperatures. Am Jour Sci 277:1315-1351

Williams LA, Crerar DA (1985) Silica diagenesis, II. General mechanisms. J Sediment Petrol 55(3):312-321

Williams LA, Parks GA, Crerar DA (1985) Silica diagenesis, I. Solubility controls. J Sediment Petrol 55(3):312321

Ziemniak SE, Jones ME, Combs KES (1995) Magnetite solubility and phase stability in alkaline media at elevated temperatures. J Solut Chem 24(9):837-877 